\title{
Distribution of ultraphytoplankton in the western part of the North Pacific subtropical gyre during a strong La Niña condition: relationship with the hydrological conditions
}

\author{
M. Girault ${ }^{1}$, H. Arakawa ${ }^{1}$, A. Barani ${ }^{2}$, H. J. Ceccaldi ${ }^{2}$, F. Hashihama ${ }^{1}$, S. Kinouchi ${ }^{1}$, and G. Gregori ${ }^{2}$ \\ ${ }^{1}$ Department of Ocean Sciences, Tokyo University of Marine Science and Technology, 5-7 Konan 4, Minato-ku, Tokyo \\ 108-8477, Japan \\ ${ }^{2}$ Aix-Marseille Université, Mediterranean institute of oceanography MIO UM110, Université du Sud Toulon-Var, \\ CNRS/INSU IRD, 13288, Marseille, cedex 09, France
}

Correspondence to: M. Girault (d092028@kaiyodai.ac.jp, gerald.gregori@univ-amu.fr)

Received: 28 February 2013 - Published in Biogeosciences Discuss.: 25 March 2013

Revised: 8 July 2013 - Accepted: 29 July 2013 - Published: 11 September 2013

\begin{abstract}
The distribution of ultraphytoplankton was investigated in the western North Pacific Subtropical Gyre (NPSG) during La Niña, a cold phase of El Niño Southern Oscillation (ENSO). Observations were conducted in a north-south transect $\left(33.6-13.25^{\circ} \mathrm{N}\right)$ along the $141.5^{\circ} \mathrm{E}$ meridian in order to study the ultraplankton assemblages in various oligotrophic conditions. Analyses were performed at the single cell level by analytical flow cytometry. Five ultraphytoplankton groups (Prochlorococcus, Synechococcus, picoeukaryotes, nanoeukaryotes and nanocyanobacteria-like) defined by their optical properties were enumerated in three different areas visited during the cruise: the Kuroshio region, the subtropical Pacific gyre and a transition zone between the subtropical Pacific gyre and the Warm pool. Prochlorococcus outnumbered the other photoautotrophs in all the investigated areas. However, in terms of carbon biomass, an increase in the relative contribution of Synechococcus, picoeukaryotes and nanoeukaryotes was observed from the centre of the subtropical gyre to the Kuroshio area. In the Kuroshio region, a peak of abundance of nanoeukaryotes observed at the surface suggested an increase in nutrients likely due to the vicinity of a cold cyclonic eddy. In contrast, in the salinity front along the isohaline 35 and anticyclonic eddy located around $22.83^{\circ} \mathrm{N}$, the mainly constant distribution of Prochlorococcus from the surface down to $150 \mathrm{~m}$ characterised the dominance by these microorganisms in high salinity and temperature zone. Results suggested that the distribution of nanocyanobacteria-like is also closely linked to
\end{abstract}

the salinity front rather than low phosphate concentration. The maximum abundance of ultraphytoplankton was located above the SubTropical Counter Current (STCC) at depths $>100 \mathrm{~m}$ where higher nutrient concentrations were measured. Finally, comparison of the ultraphytoplankton concentrations during El Niño (from the literature) and La Niña (this study) conditions seems to demonstrate that La Niña conditions lead to higher concentrations of Synechococcus in the Subtropical gyre and a lower abundance of Synechococcus in the Kuroshio region. Our results suggest that the west part of NPSG is a complex area, where different water masses, salinity fronts and eddies lead to a heterogeneous distribution of ultraphytoplankton assemblages in the upper layer of the water column.

\section{Introduction}

In the subtropical Pacific Ocean, phytoplankton assemblages are mainly dominated by small-sized organisms from $0.2 \mu \mathrm{m}$ to $2 \mu \mathrm{m}$ in diameter ( $\mathrm{Li}$ et al., 2011). These microorganisms have been reported to significantly contribute to the biological pump and export of carbon in oligotrophic conditions (Richardson and Jackson, 2007). Phytoplankton distribution is a well-documented topic in the North Pacific Subtropical Gyre (NPSG), especially in the vicinity of the equator and in the centre of the subtropical gyre (Campbell and Vaulot, 1993; Suzuki et al., 1995; Campbell et al., 
1997; Blanchot et al., 2001). Ultraphytoplankton, consisting of photoautotrophic prokaryotes (such as picocyanobacteria, Prochlorococcus and Synechococcus) and eukaryotes $(<10 \mu \mathrm{m})$, are distributed in the euphotic layer between the surface and $200 \mathrm{~m}$, depending on irradiance, hydrography line, climatic conditions such as El-Niño Southern Oscillation (ENSO), nutrient availability (Matsumoto et al., 2004) and trophic processes (predation and viral lysis).

However, only a few reports, mainly conducted under the warm phase of the ENSO (El Niño), have addressed the distribution of phytoplankton in the western part of the NPSG (Zhang et al., 2008; Kitajima et al., 2009). Nutrients in this area were reported to be depleted in the surface layer (Hashihama et al., 2009). Under such oligotrophic conditions, investigations of phytoplankton communities based only on pigment measurements are more difficult due to the low cellular pigment content induced by irradiance and nutrient limitation (Goericke and Montoya, 1998; Henriksen et al., 2002).

In this study, we used analytical flow cytometry in order to assess the ultraphytoplanktonic community distribution where the nutrient concentrations were close to the detection limit and chlorophyll $a$ maxima observed at the limit of the euphotic layer. We have investigated the distribution of picoand nanophytoplankton during a North-South transect from $33.6^{\circ} \mathrm{N}$ to $13.25^{\circ} \mathrm{N}$. The heterotrophic prokaryote distribution was also addressed in this study. Along this transect, we looked for the relationships between the spatial variability of dominant ultraphytoplankton communities and the environmental factors and water masses during a notable La Niña event.

\section{Materials and methods}

\subsection{Study area and sampling strategy}

Seawater samples were collected during the Tokyo-Palau cruise conducted in the western part of NPSG along $141.5^{\circ} \mathrm{E}$ transect (Fig. 1). The cruise was carried out from 17 January to 8 February 2011 on board RT/V Shinyo Maru. During this cruise, 12 stations between $33.6^{\circ} \mathrm{N}$ and $13.25^{\circ} \mathrm{N}$ were sampled. Seawater samples were collected without replicates at several depths between the surface and $200 \mathrm{~m}$ with $2.5 \mathrm{~L}$ Niskin bottles mounted on a Conductivity-TemperatureDepth/Carousel system equipped with an in situ fluorometer. Due to the severe climatic conditions, seawater samples were collected only at the surface with a single Niskin bottle between stations 1 and 4 and CTD casts were not performed. However, eXpendable Conductivity/Temperature/Depth profiling systems (XCTD) were used to measure the temperature and salinity between stations 1 and 4 . This is why, in this manuscript, data from the surface and data along the water column are addressed separately (e.g. for principal component analysis). From station 5, the sampling depths were de-

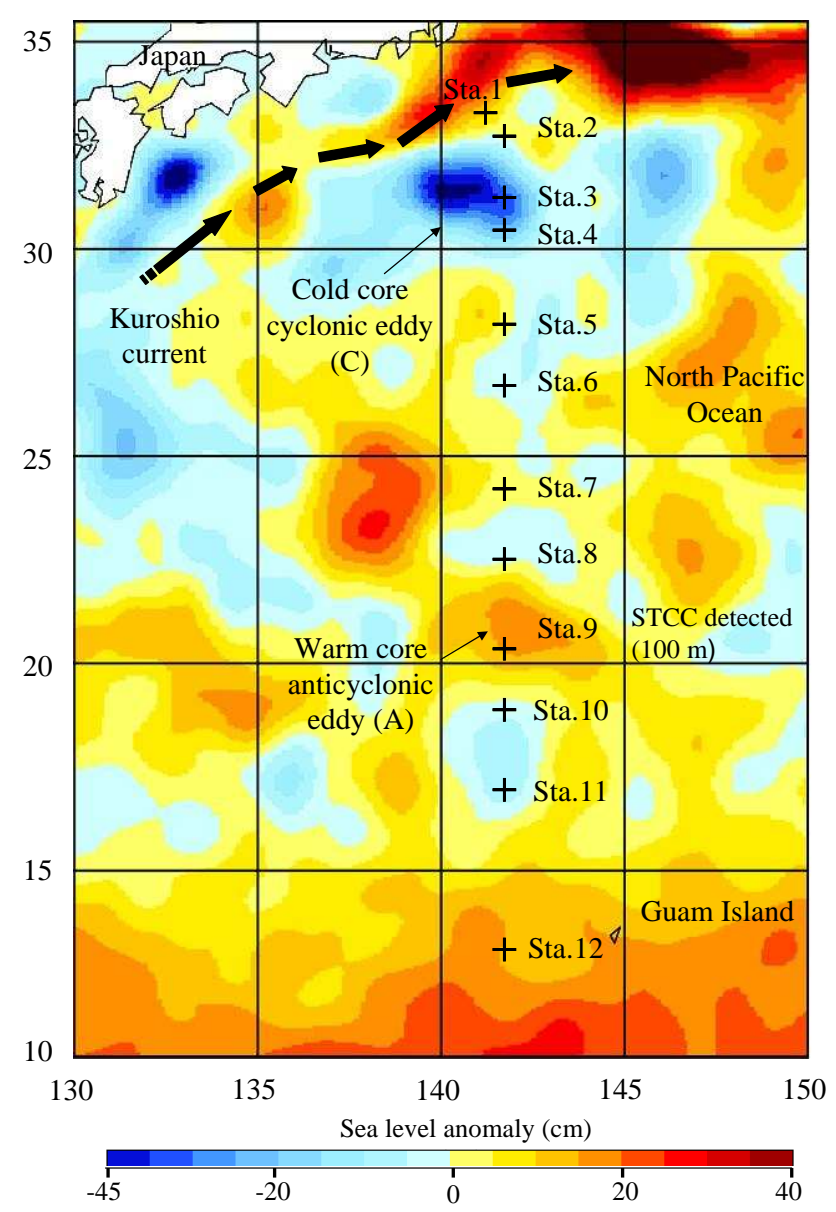

Fig. 1. Map of the sea level anomaly $(\mathrm{cm})$ in the west part of the North Pacific subtropical gyre. Thick black arrows display the direction of the Kuroshio Current. Black crosses are the location of the sampling stations during the cruise.

cided based on the chlorophyll $a$ profile measured with an in situ fluorometer during the downward cast. Due to the maximal depth sampled in this study $(200 \mathrm{~m})$, we did not correct the temperature for adiabatic heating as a result of compression. The light parameters have been monitored at five stations $(5,7,9,11,12)$ using a Profiling Reflectance Radiometer (PRR 600 Biospherical Instrument ${ }^{\circledR}$ ). The euphotic layer was measured as the depth of $1 \%$ of photosynthetically active radiation at noon. The mixed layer depths were calculated according to the $\Delta \sigma_{O}=0.15 \mathrm{~kg} \mathrm{~m}^{-3}$ (relative to $z=10 \mathrm{~m}$, Thomson and Fine, 2003).

\subsection{Nutrient analysis}

Nutrient concentrations in the seawater samples were determined by using highly sensitive colorimetry that consisted of an AutoAnalyser II (Technicon, now SEAL Analytical) and Liquid Waveguide Capillary Cells (World Precision Instruments) as described in Hashihama et al. (2009) for nitrate + nitrite and soluble reactive phosphorus and in 
Hashihama and Kanda (2010) for silicic acid. The detection limits were 3,3 , and $11 \mathrm{nM}$ for nitrate + nitrite, soluble reactive phosphorus, and silicic acid, respectively. Seawater collected from the surface of the western subtropical North Pacific and preserved for $>1 \mathrm{yr}$ was used as nitrate + nitrite blank, and nitrate + nitrite concentrations of this blank water was determined by the chemiluminescent technique (Garside, 1982). The soluble reactive phosphorus and silicic acid blank were prepared by the MAGIC procedure (Karl and Tien, 1992). Soluble reactive phosphorus consists mainly of orthophosphate (hereafter referred to as phosphate). Because nitrite was not substantially detectable, nitrate + nitrite was referred to as nitrate hereafter. Due to the lack of data from stations 10 to 12, data were not shown below the depth of $70 \mathrm{~m}$. By using the nutrient concentrations the Redfield and Brzezinski ratios have been calculated on the basis of the following stoichiometries: $\mathrm{Si}: \mathrm{N}: \mathrm{P}=15: 16: 1$ (Brzezinski, 1985).

\subsection{Altimetry and large scale climatic condition}

The altimeter data (sea level anomaly) were produced by Ssalto/Duacs and distributed by Aviso, with support from CNES (http://www.aviso.oceanobs.com/duacs/). The sea level anomaly map centred on the 18/01/2011 (the process generates maps compiling data collected six weeks before and after the chosen date) (Fig. 1) was plotted using the Panoply software from the NASA (http://www.giss.nasa. gov/tools/panoply/). The multivariate ENSO index (MEI) data were used to describe the large scale climatic condition. The data were available from the NOAA website (http: //www.esrl.noaa.gov/psd/enso/mei/) (Fig. 2).

\subsection{Flow cytometry (FCM) and carbon biomass}

Seawater samples collected from the Niskin bottles were prefiltered through a $100 \mu \mathrm{m}$ mesh size net to prevent any clogging of the flow cytometer. Cryovials $\left(5 \mathrm{~cm}^{3}\right)$ were filled with $4.5 \mathrm{~cm}^{3}$ subsamples that were preserved with $0.5 \mathrm{~cm}^{3}$ of a $20 \%$ formaldehyde solution ( $2 \%$ final concentration) for ultraphytoplankton analysis. Cryovials $\left(2 \mathrm{~cm}^{3}\right)$ were filled with $1.8 \mathrm{~cm}^{3}$ subsamples that were preserved with $0.2 \mathrm{~cm}^{3}$ of a $20 \%$ formaldehyde solution (2\% final concentration) for heterotrophic prokaryote analysis. Samples were then rapidly frozen in liquid nitrogen and stored in a deep freezer $\left(-60^{\circ} \mathrm{C}\right)$ until analysis at the PRECYM flow cytometry platform (http://precym.com.univ-mrs.fr). In the laboratory, cryovials were rapidly thawed at room temperature and analysed using a FACSCalibur flow cytometer (BD Biosciences ${ }^{\circledR}$ ) of the PRECYM flow cytometry platform. The flow cytometer is equipped with a blue $(488 \mathrm{~nm})$ air-cooled argon laser and a red $(634 \mathrm{~nm})$ diode laser. For each particle (cell), five optical parameters were recorded: two light scatter signals, namely forward and right angle light scatter, and three fluorescences corresponding to emissions in green (515-

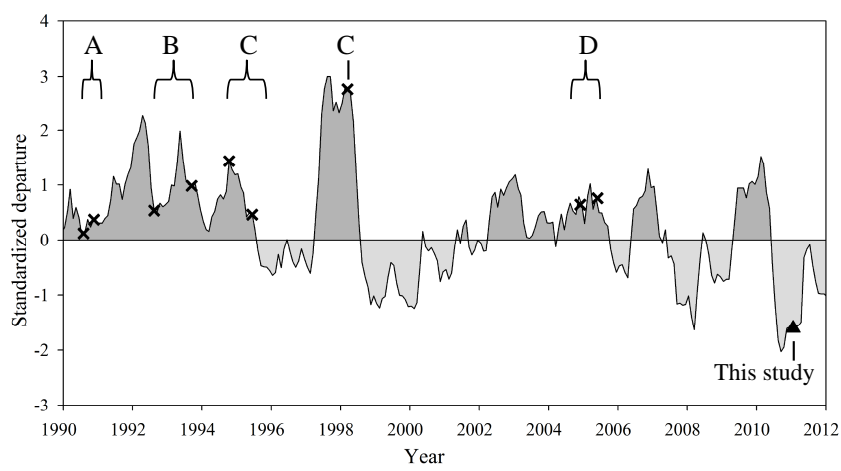

Fig. 2. Multivariate El Niño-Southern oscillation Index, (MEI) between January 1990 and 2012. The dark grey shaded area above the line shows the El Niño condition period and light grey below the line is the La Niña condition period. The black crosses show the previous observations conducted in the western part of North Pacific subtropical gyre. The black triangle shows the Tokyo Palau cruise (this study). A, B, C, D are the studies of Shimada et al. (1993), Suzuki et al. (1997), Horimoto et al. (2001) and Kitajima et al. (2009), respectively. Shimada et al. (1993) sampled seawater during two cruises (from August to September and from November to December). Suzuki et al. (1997) conducted experiments in August-September 1992 and 1993. Horimoto et al. (2001) collected samples during 3 cruises (October 1994, June 1995 and March 1998) and Kitajima et al. (2009) during two cruises (November to December 2004 and May to June 2005).

$545 \mathrm{~nm})$, orange $(564-606 \mathrm{~nm})$ and red $(653-669 \mathrm{~nm})$ wavelength ranges. Data were collected using the CellQuest software (BD Biosciences ${ }^{\circledR}$ ). The analysis and identification of ultraphytoplankton groups were performed a posteriori using SUMMIT v4.3 software (Beckman Coulter). For each sample the runtime of the flow cytometer was set up at 3 and $2 \mathrm{~min}$ for ultraphytoplankton and heterotrophic prokaryote analyses, respectively. The sample flow rate was about $50 \mu \mathrm{L} \mathrm{min}^{-1}$ (corresponding to the "Med" flow rate of the flow cytometer).

Five ultraphytoplankton groups (Prochlorococcus, Synechococcus, picoeukaryotes, nanoeukaryotes, and nanocyanobacteria-like) were resolved without any staining on the basis of their scatter and fluorescence properties (Fig. 3). Combining the light scatter and fluorescence properties of each "particle" (cell), ultraphytoplankton was optically resolved in three different groups of picophytoplankton (the prokaryotes: Prochlorococcus, Synechococcus, and eukaryotes with a diameter size ranging from 0.2 to $2 \mu \mathrm{m})$ and two groups of nanophytoplankton (nanoeukaryotes and nanocyanobacteria-like with a diameter size ranging from 2 to $10 \mu \mathrm{m})$. Separation of picoeukaryotes and nanophytoplankton was performed by adding $2 \mu \mathrm{m}$ yellow-green fluorescent cytometry beads (Fluoresbrite YG $2 \mu \mathrm{m}$, Polyscience Inc.) to the samples. Trucount ${ }^{\mathrm{TM}}$ calibration beads (Becton Dickinson Biosciences) were also added to the samples as an internal standard both to 
a)

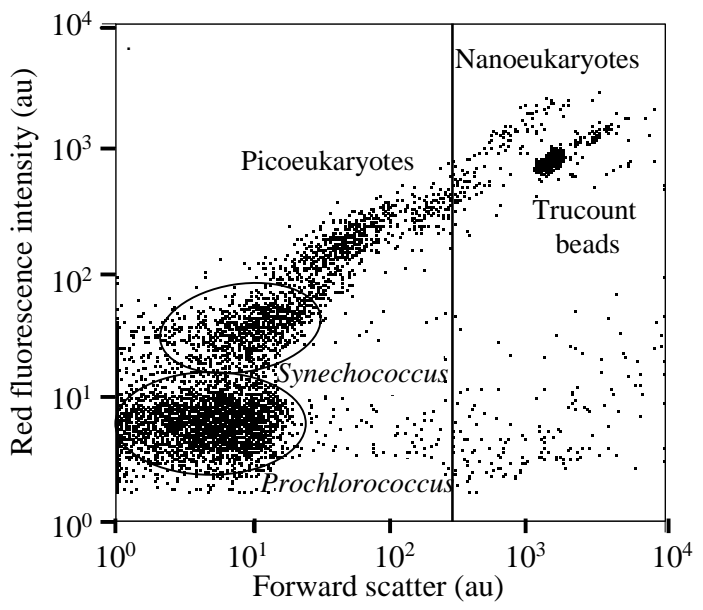

b)

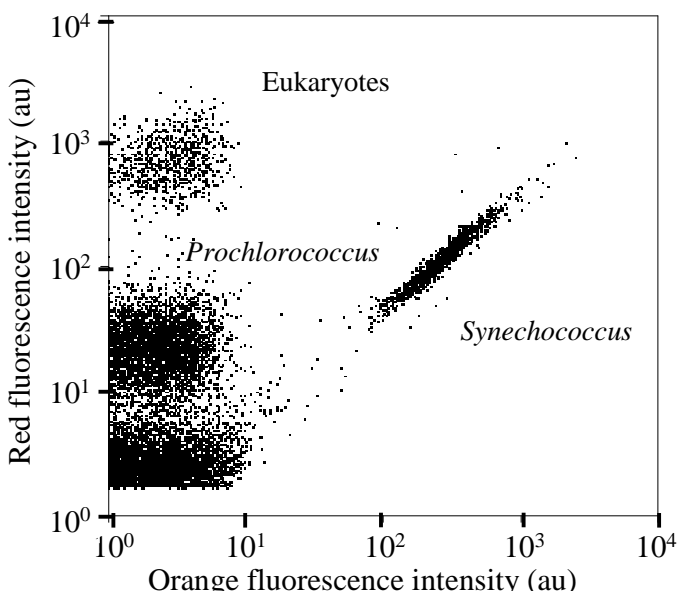

c)

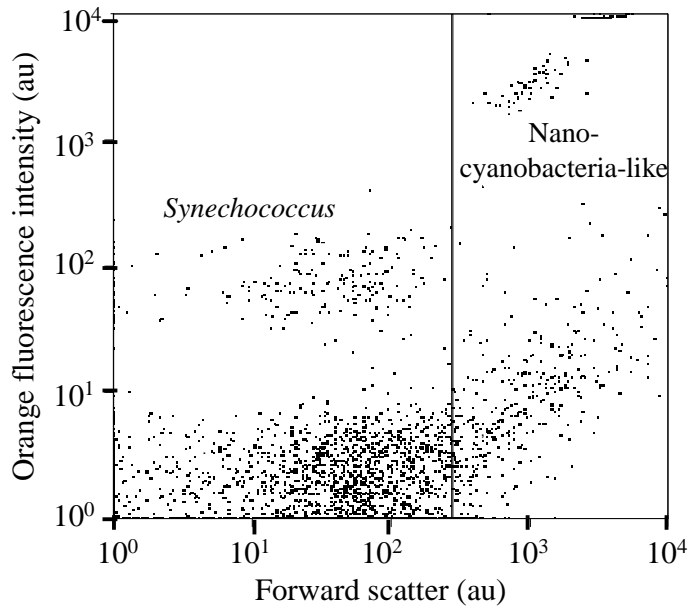

Fig. 3. Resolution by flow cytometry of the ultraphytoplankton assemblage composition during the Tokyo-Palau cruise. Panels (a) and (b) display cytograms of red fluorescence (chlorophyll $a$ ) versus forward scatter (size) and orange fluorescence (phycoerythrin) resolving four cell groups: Synechococcus, Prochlorococcus, picoeukaryotes and nanoeukaryotes in samples collected at station 8 $(100 \mathrm{~m}$ depth). Panel (c) displays the orange fluorescence versus forward scatter and discriminates the nanocyanobacteria-like to the Synechococcus in the sample collected at $3 \mathrm{~m}$ depth of the station 11. The beads are the Trucount calibration beads (Beckton Dickinson). monitor the instrument stability and to determine the volume analysed by the instrument. This is mandatory to compute the cell abundances. The nanophytoplankton community was characterised by the highest intensities in light scatter and red fluorescence (chlorophyll $a$ related). Prochlorococcus and picoeukaryotes were resolved thanks to their lower light scatter, red fluorescence intensities and low orange fluorescence. Synechococcus were recognised by their small intensities in light scatter and red fluorescence, concomitant with higher values of orange fluorescence due to the presence of phycoerythrin. An additional group reported here as nanocyanobacteria-like was observed at several stations during the cruise. This group has the highest value of orange fluorescence and was separated from Synechococcus thanks to the strong intensities of forward scatter (Sato et al., 2010). As no molecular analyses were performed to confirm the identification of nanocyanobacteria, this flow cytometry group was cautiously named nanocyanobacteria-like in this manuscript.

Ultraphytoplankton abundances were also expressed in term of carbon biomass using conversion factors reported in the literature. The factors 49, 250, 671, 2100 and $3498 \mathrm{fg} \mathrm{C} \mathrm{cell}^{-1}$ were used to convert Prochlorococcus, Synechococcus, picoeukaryotes, nanocyanobacteria and nanoeukaryotes, respectively (Cailliau et al., 1996; Kana and Glibert, 1987; Campbell and Yentsch, 1989; Karayanni et al., 2005).

Although this study focuses on the distribution of ultraphytoplankton, heterotrophic prokaryotes were also enumerated as part of the Tokyo-Palau project. Heterotrophic prokaryotes were analysed after staining of their nucleic acid using SYBR Green II (Molecular Probes ${ }^{\circledR}$ ) on the basis of the methods detailed in Marie et al. (1999) and Lebaron et al. (1998), modified by Gregori et al. (2003). The overlapping of stained Prochlorococcus in the green fluorescence versus side scatter cytograms was accounted for by using the red fluorescence (induced by the chlorophyll) that distinguishes Prochlorococcus from heterotrophic prokaryotes (Sieracki et al., 1995). In this study, heterotrophic prokaryotes will be considered as a whole group, without distinction of subclusters related to the nucleic acid content. The heterotrophic prokaryote abundance was expressed in terms of carbon biomass using a conversion factor of $15 \mathrm{fg} \mathrm{C} \mathrm{cell}^{-1}$ (Caron et al., 1995).

\subsection{Statistical analyses}

Statistical analyses were performed using the R software (vegan package) and Biplot macro for Excel $^{\circledR}$ (Lipkovich and Smith, 2002). Kruskal-Wallis tests were performed in order to compare the abundances of ultraphytoplankton at the various sampling stations.

To analyse the multivariate dataset, principal component analyses (PCA) and redundancy analysis (RDA) were also performed. 
PCA reduces the data dimensionality by performing a covariance analysis between factors. The procedure transforms a number of possibly correlated variables into a smaller number of uncorrelated factors called principal components (Pearson, 1901). Due to the severe weather conditions at the beginning of the sampling cruise, two PCAs were performed in this study: (i) using the data collected at the surface only and (ii) using the data collected at various depths from stations 5 to 11 . Choice of two different PCAs was motivated by the lack of sampling point below the seawater surface from stations 1 to 4 . Station 12 was not included in the PCA performed on the vertical profiles because several variables were missing.

In addition to the PCA, the relationships between phytoplankton communities and environmental factors were investigated by using RDA. Data were $\log _{10}(x+1)$-transformed to correct for the large differences in scale among the original variables. Then, Monte-Carlo tests were used to test the significance of the contribution of the various environmental variables to explain the microorganism distribution by the RDA. Partial RDA was also used to evaluate the effects of each explanatory variable set on the organism composition (Liu, 1997). Two RDA were performed using (i) the surface observations only and (ii) the vertical profiles (Sta. 5 to 11). However, this manuscript only consider the result for the vertical profiles because the Monte-Carlo test statistics were not significant for the surface data ( $P=0.1$, using 999 permutations).

Hierarchical ascendant classifications were also performed to readily regroup similar stations together (low withinvariability). Hierarchical clustering was performed using the first and second axes of the PCA which explained more than $60 \%$ of the inertia.

\section{Results}

\subsection{Hydrographic conditions}

Seawater was sampled along a $2300 \mathrm{~km}$ transect in January 2011 during a significant cold phase of ENSO (La Niña) (Fig. 2). Sea level anomaly map shows two main eddies over the sampling area, (i) a cold core cyclonic eddy $\left(\mathrm{C}, 31^{\circ} \mathrm{N}\right.$, $\left.141^{\circ} \mathrm{E}\right)$ and (ii) a warm core anticyclonic eddy (A, $20.5^{\circ} \mathrm{N}$, $142^{\circ}$ E) (Fig. 1). Stations 3 and 9 were located in the vicinity of $\mathrm{C}$ and $\mathrm{A}$, respectively. Figure 4a illustrates the vertical distribution of temperature $(0-200 \mathrm{~m})$ measured along the transect $\left(141.5^{\circ} \mathrm{E}\right)$. Figure $4 \mathrm{a}$ shows a north-south temperature gradient with a minimum at station $1\left(18.5^{\circ} \mathrm{C}\right)$ and a maximum at station $12\left(28.2^{\circ} \mathrm{C}\right)$. At station 3 , the low temperature $\left(18.6^{\circ} \mathrm{C}\right)$ in the near surface and the occurrence of a thermocline dome at $150 \mathrm{~m}$ depth evidenced the pumping effect of the anticlockwise eddy C. Figure $4 \mathrm{~b}$ shows the vertical distribution of salinity measured during the cruise. The lower salinities $(<34.7)$ were observed from stations 1 to 4
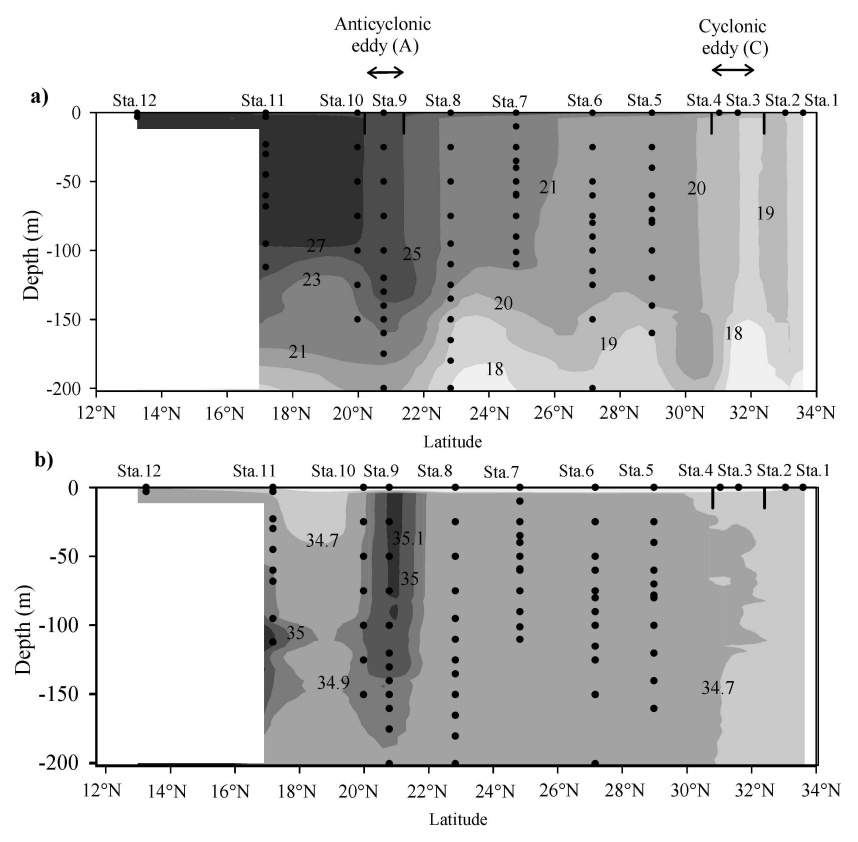

Fig. 4. Vertical distributions of temperature (a) and salinity (b) measured along the studied transect $\left(141.5^{\circ} \mathrm{E}\right)$. The location of the observed stations is indicated in the upper scale axis. Black dots illustrate the sampling depths. Cold core cyclonic eddy (C) and warm core anticyclonic eddy (A) identified with the sea level anomaly map are shown with small black arrows.

and in the upper $50 \mathrm{~m}$ between station 10 and 11 . Station 9 was located within a thermohaline front.

The temperature-salinity diagram (Fig. 5) highlights three major groups of stations (stations 1-4; stations 5-8; stations 9-11). The four northernmost stations were characterised by a low salinity (34.62 to 34.71 ) and temperatures ranging from $17.1^{\circ} \mathrm{C}$ to $19.6^{\circ} \mathrm{C}$. The Kuroshio region term is used to characterise this group of stations according to Sekine and Miyamoto (2002). Salinity and temperature of the second group (Subtropical gyre, stations 58) were in the ranges $34.7-34.8$ and $18.2-22.5^{\circ} \mathrm{C}$, respectively. Although the profiles were similar between $18^{\circ} \mathrm{C}$ and $21^{\circ} \mathrm{C}$, differences in the temperature-salinity curves of stations 7 and 8 were observed in the upper layer (surface to $150 \mathrm{~m}$ depth). In the upper layer the salinity at station 7 were higher than station 8 . The last group includes the southernmost stations (Transition zone, stations 9-10-11). These stations were characterised by a high variability in salinity (34.6 to 35.1$)$ and temperature $\left(18.5^{\circ} \mathrm{C}\right.$ to $\left.27.5^{\circ} \mathrm{C}\right)$. Among the third group, salinity ranged from 34.86 to 35.1 at station 9 and remained higher than other stations. Similarly, the lowest amplitude of temperature was observed between the surface $\left(26^{\circ} \mathrm{C}\right)$ and $200 \mathrm{~m}$ depth $\left(19.8^{\circ} \mathrm{C}\right)$. The seawater temperature from stations 9 to 11 was lower than $28.5^{\circ} \mathrm{C}$. 


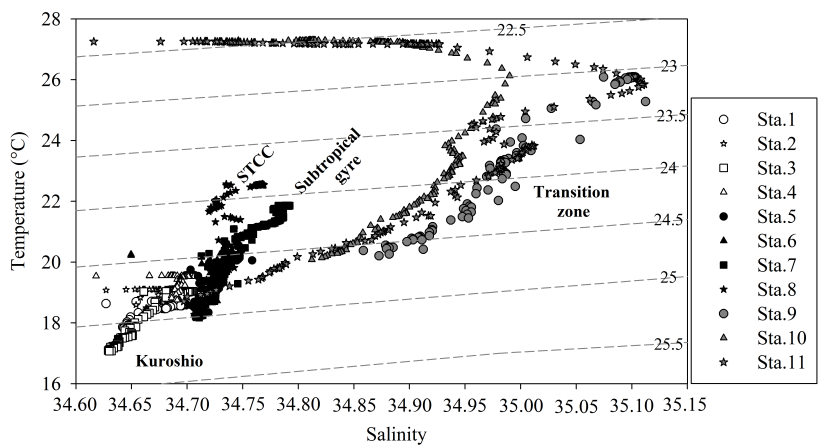

Fig. 5. Temperature-salinity diagram from surface to $200 \mathrm{~m}$ between stations 1 and 11 . The three groups of stations are shown with different colours: stations in the Kuroshio region (1-4) by a white symbol; stations in the centre of the subtropical gyre (5-8) in black; and stations in the transition zone (9-11) in dark grey.

\subsection{Nutrient conditions}

Figure 6 shows the vertical distribution of nutrients between stations 5 and 12. The general pattern of the phosphate distribution was characterised by a depletion of surface waters $(<20 \mathrm{nM})$ between stations 7 and 11 (Fig. 6a). At the northernmost and southernmost ends (stations 5, 6, and 12) phosphate concentrations ranged from $20 \mathrm{nM}$ at the surface to $160 \mathrm{nM}$ in the deeper layer ( $200 \mathrm{~m})$. In this section, the highest phosphate concentrations were observed below the depth of $150 \mathrm{~m}$. Nitrate concentrations values varied from $<3 \mathrm{nM}$ to $929 \mathrm{nM}$ (station 9, $200 \mathrm{~m}$, Fig. 6b). Although a slight increase in nitrate concentration was observed at stations 5 and $6(100 \mathrm{nM})$, the distribution globally paralleled phosphate concentrations. Contrasting to nitrate and phosphate distributions, high concentrations of silicic acid were observed in the upper layer from station 5 to station 8 (Fig. 6c). The concentrations of silicic acid varied from $0.3 \mu \mathrm{M}$ (station $7,30 \mathrm{~m}$ ) to $2.4 \mu \mathrm{M}$ (station 9, $150 \mathrm{~m}$ ). At station 8 , between $100 \mathrm{~m}$ and $120 \mathrm{~m}$ depth, phosphate, nitrate, and silicic acid concentrations were higher than surrounding sampling depths. Except for the station 3, the phosphate and nitrate concentrations at the surface of the Kuroshio area ranged from 8 to $20 \mathrm{nM}$ and from $240 \mathrm{nM}$ to $297 \mathrm{nM}$, respectively. The concentrations of phosphate $(96 \mathrm{nM})$ and nitrate $(630 \mathrm{nM})$ at station 3 were the highest measured in the surface layer. However, the silicic acid concentration at station $3(1.01 \mu \mathrm{M})$ was the lowest measured in the Kuroshio region (average $1.38 \mu \mathrm{M}$ ).

The Redfield and Brzezinski ratios calculated among the stations are mainly characterised by a potential limitation in nitrogen (Fig. 7). The second potential limitation was phosphorus and silica. Two different groups were observed for the stations and were discriminated using circles (Fig. 7). A first group (stations 1 to 6 ) was characterised by a high $\mathrm{N}: \mathrm{P}$ ratio close to phosphorus potential limitation. In contrast, the second group, consisting of $92 \%$ of samples collected in the upper $50 \mathrm{~m}$ (stations 7 to 12 ), had a lower $\mathrm{N}: \mathrm{P}$ stoichiome-
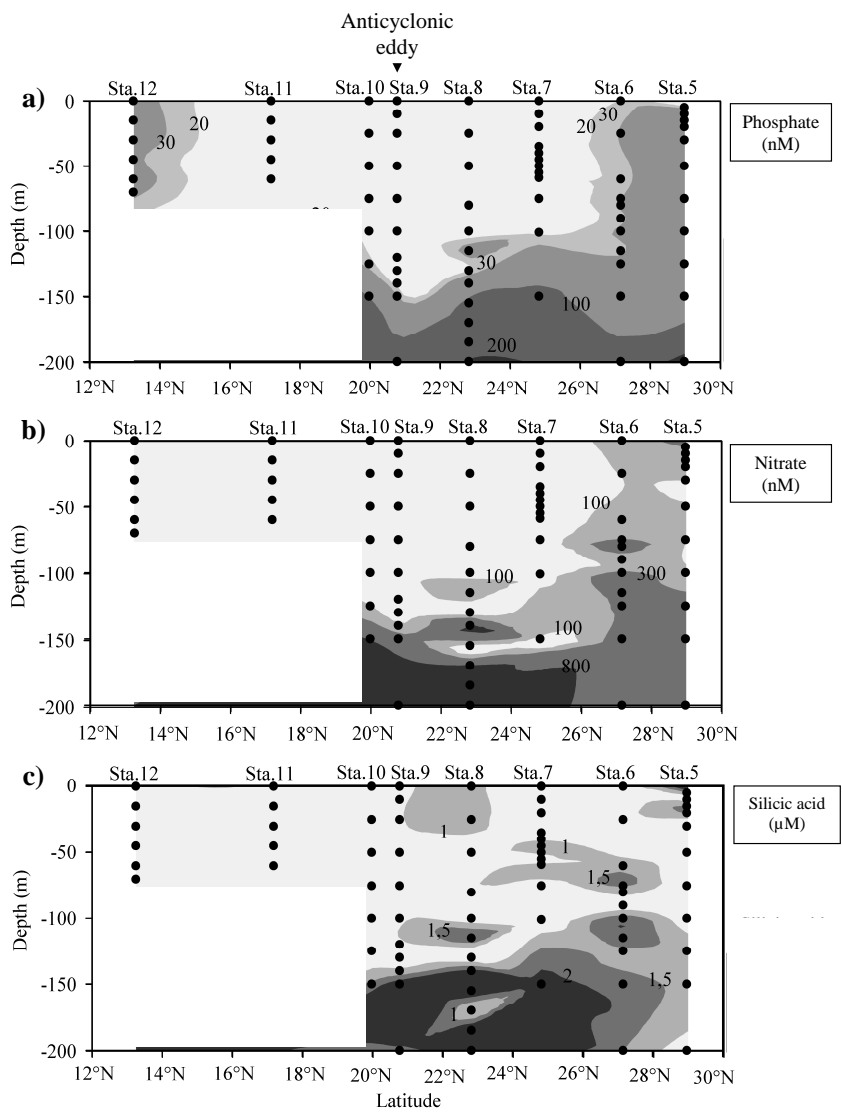

Fig. 6. Vertical distribution of nutrient concentrations measured between stations 5 and 12: Distribution of (a) phosphate (nM) (b) nitrate $(\mathrm{nM})$, and (c) silicic acid $(\mu \mathrm{M})$. The black dots display the sampled depths and the names of the stations are indicated in the upper scale axis.

try (0.18 to 1.38$)$ and a high ratio of $\mathrm{Si}: \mathrm{N}$ (59 to 514). The seawater sampled deeper than $50 \mathrm{~m}$ was characterised by a progressive increase in the molar ratio $\mathrm{N}: \mathrm{P}$ and a decrease in the $\mathrm{Si}: \mathrm{N}$ ratio at the same time. Station 3 (black dot) has a particular pattern due to its $\mathrm{Si}: \mathrm{P}$ ratio lower than 15 , observed at the surface. In contrast, station 9 (black squares) located near the anticyclonic eddy had the highest $\mathrm{Si}$ : P ratio of the cruise.

\subsection{Microbial community composition and distribution}

Flow cytometry analyses made it possible to discriminate five ultraphytoplankton clusters on the basis of the cellular optical properties (light scatter and fluorescence). Figure 8 illustrates the concentrations of Synechococcus, Prochlorococcus, picoeukaryotes and nanoeukaryotes at the surface from station 1 to 12 . Two main patterns were identified during the cruise: (i) Synechococcus and Prochlorococcus abundance peaks centred on station 8 , (ii) a significant difference in the picoeukaryote, nanoeukaryote and nanocyanobacterialike concentrations between the group defined by stations 1 


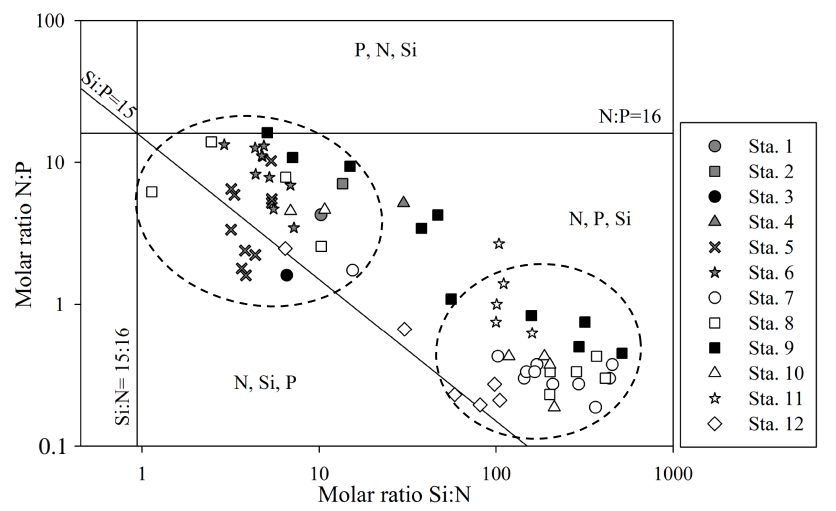

Fig. 7. $\mathrm{Si}: \mathrm{N}: \mathrm{P}$ molar ratio of all data collected during the Tokyo Palau cruise. In each area, delimited by the Brzezinski (1985) $\mathrm{Si}: \mathrm{N}: \mathrm{P}=15: 16: 1$, the potential limiting nutrient are shown in order of priority. The black symbols show the sampling depth near the cyclonic and anticyclonic gyres (stations 3 and 9, respectively). The black dotted circles discriminated two groups of sampling points depending on their nutrient ratios.

to 8 and the group defined by stations 9 to 12 (Kruskal-Wallis one-way analysis of variance, $n=36, p$ value $<0.05$ ). Synechococcus concentrations at the edge of the transect ranged from $1.94 \times 10^{3}$ cells cm $\mathrm{cm}^{-3}$ to $8.27 \times 10^{3} \mathrm{cells} \mathrm{cm}^{-3}$ (northern and southern side respectively). The maximum abundance of Synechococcus was observed at station 8 $\left(2.73 \times 10^{4}\right.$ cells cm$\left.^{-3}\right)$. Except for station 4, Prochlorococcus were more abundant than Synechococcus and their abundances ranged from $2.05 \times 10^{3}$ cells cm$^{-3}$ (station 12) to $4.22 \times 10^{5}$ cells cm$^{-3}$ (station 8 ). Picoeukaryote and nanoeukaryote concentrations were close to 700 cells cm $\mathrm{cm}^{-3}$ at the southern stations and drastically increased between $20^{\circ} \mathrm{N}$ and $22.83^{\circ} \mathrm{N}$ (up to $6.4 \times 10^{3}$ cells cm${ }^{-3}$ ). Few variations in abundances were observed from station 1 to sta-

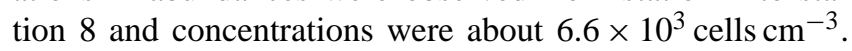
Nanoeukaryote abundances slightly decreased in the northern part of the transect, except for station 3 near the cold cyclonic eddy $\mathrm{C}$ where the maximum abundance was found. In contrast, nanocyanobacteria-like concentrations were mainly observed between station 9 and station 12 . With the peak of abundance at station 11 ( $312 \mathrm{cells} \mathrm{cm}^{-3}$, right axis), nanocyanobacteria-like had the lowest concentration compared with the abundance of other populations. The distribution of heterotrophic prokaryotes abundance at the surface is also shown in Fig. 8. The concentrations ranged from $4.16 \times 10^{5}$ cells cm$^{-3}$ (Station 9) to $2.33 \times 10^{6}$ cells cm$^{-3}$ (Station 4). Except for these two extreme values, abundance of the heterotrophic prokaryotes was centred around $1 \times 10^{6}$ cells cm${ }^{-3}$ along the transect.

Figure 9a displays the vertical distribution of Synechococcus between stations 5 and 12. Two different zones corresponding to stations 5 to 8 and stations 9 to 12 , respectively were distinguished based on the cell abundances.

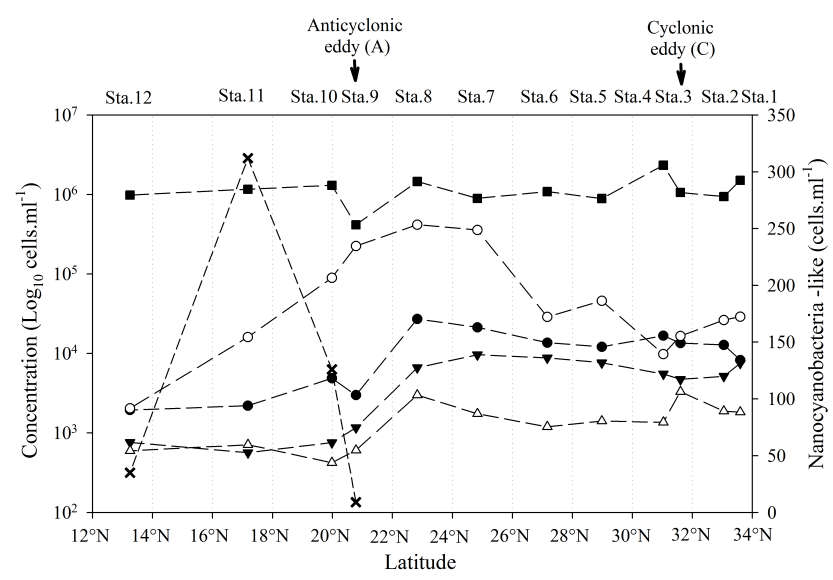

Fig. 8. Abundances of heterotrophic prokaryotes and ultraphytoplankton at surface depending on the latitude along the $141.5^{\circ} \mathrm{E}$ meridian. The sampling stations are given on the upper scale axis. The black squares represent the concentration of the heterotrophic prokaryotes, the white circles the Prochlorococcus, the black circles the Synechococcus, the black and the white triangles the abundances of picoeukaryotes and nanoeukaryotes, respectively. The black crosses show the nanocyanobacteria-like (right axis). Nanocyanobacteria-like were not detected in the surface samples from the stations 1 to 8 .

Abundances of Synechococcus were higher between stations 5 and 8 than in the area south of station 9. Synechococcus were widely distributed from the surface down to $150 \mathrm{~m}$ depth in the group of the northernmost stations. However, lower concentrations were observed in the area south of station 9 . In the stations between $28.98^{\circ} \mathrm{N}$ and $22.83^{\circ} \mathrm{N}$ (stations 5 to 8 ), the maximal abundances ranged from $40 \mathrm{~m}$ to $80 \mathrm{~m}$ depths, close to the maximum of chlorophyll $a$. (Fig. 10). In this layer the maximum concentration $\left(3.04 \times 10^{4}\right.$ cells cm $\left.{ }^{-3}\right)$ was measured at station 8 at $50 \mathrm{~m}$ depth. Prochlorococcus were mainly distributed from the surface down to $110 \mathrm{~m}$ between stations 7 and 9 (Fig. 9b). From station 10, the highest concentrations were observed between $70 \mathrm{~m}$ and $120 \mathrm{~m}$ depths and matched with the subsurface chlorophyll $a$ maximum. Similarly to Synechococcus, the maximum of Prochlorococcus was measured at station 8 at $50 \mathrm{~m}$ depth $\left(4.34 \times 10^{5}\right.$ cells cm$\left.~_{-3}\right)$. As far as picoeukaryotes are concerned (Fig. 9c), the major pattern of distribution is defined by high abundances observed in the subtropical gyre seawater and low abundances measured at the southernmost stations $\left(<4.3 \times 10^{3} \mathrm{cells} \mathrm{cm}^{-3}\right)$. Between stations 5 and 12 , picoeukaryote concentrations ranged from $51 \mathrm{cells} \mathrm{cm}^{-3}$, (station $9,200 \mathrm{~m}$ depth) to $11.5 \times 10^{3}$ cells cm $\mathrm{cm}^{-3}$ (station $6,50 \mathrm{~m}$ depth). The vertical distribution of nanoeukaryotes (Fig. 9d) was characterised by several patches of relatively high concentrations among the stations (station 5, $25 \mathrm{~m}$; station $6,125 \mathrm{~m}$; station 8 surface and $50 \mathrm{~m}$; station $10,100 \mathrm{~m}$ ). Concentrations of nanoeukaryotes ranged from 69 cells cm $\mathrm{cm}^{-3}$ (station $6,150 \mathrm{~m}$ ) 

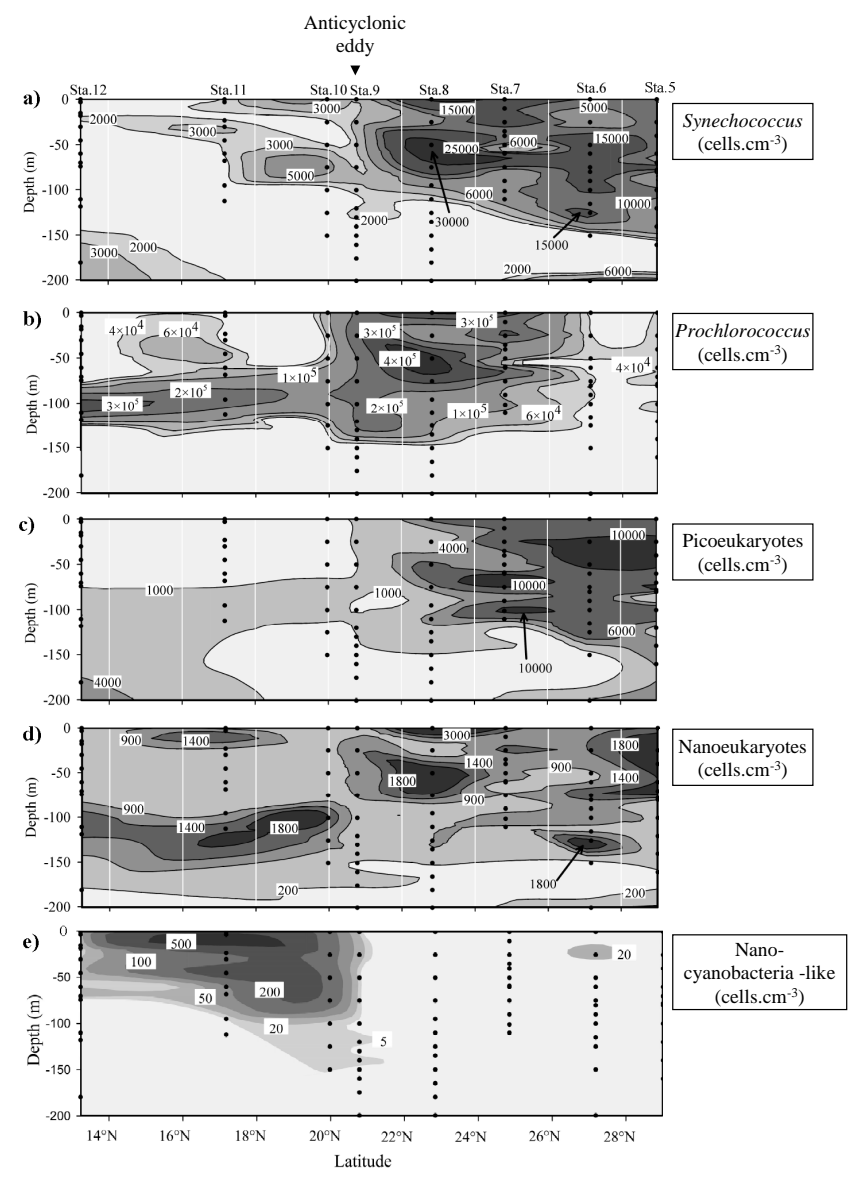

Fig. 9. Vertical abundances (cells $\mathrm{cm}^{-3}$ ) of the five ultraphytoplankton groups defined during the cruise: (a) Synechococcus, (b) Prochlorococcus, (c) picoeukaryotes and (d) nanoeukaryotes and (e) nanocyanobacteria. Black dots illustrate the sampling depth between stations 5 and 12 .

to $3 \times 10^{3}$ cells $\mathrm{cm}^{-3}$ (station 8 , surface and $50 \mathrm{~m}$ ). Figure $9 \mathrm{e}$ shows the distribution of nanocyanobacteria-like from station 5 to 12 . Nanocyanobacteria-like were mainly observed in the area south of station 9 where the concentration reached 550 cell cm$^{-3}$ at $3 \mathrm{~m}$ depth (station 11). Distribution of nanocyanobacteria-like concentration is located in the shallow layer from the surface to $100 \mathrm{~m}$. Except for station 6 $\left(25 \mathrm{~m}, 25\right.$ cells $\left.\mathrm{cm}^{-3}\right)$, concentrations were below the limit

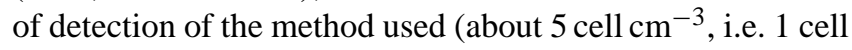
detected in the volume analysed by the flow cytometer) from station 8 to the northernmost station.

Figure 10 displays the distribution of chlorophyll $a$ and the depths of the euphotic and mixed layers (MLD). At station 3, within the cyclonic eddy in the Kuroshio region, the MLD was found at $145 \mathrm{~m}$, well above the MLD at surrounding stations 2 and $4(180 \mathrm{~m})$. At station 9, within the anticyclonic eddy, the MLD was observed at $133 \mathrm{~m}$, deeper than at surrounding stations 8 and 10 (101 and $95 \mathrm{~m}$, respectively). The bottom of the euphotic layer was mainly observed above

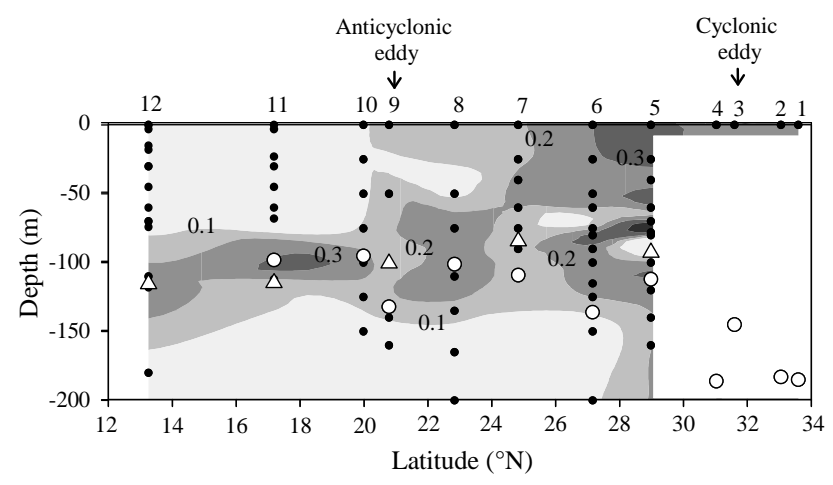

Fig. 10. Vertical profiles of chlorophyll $a$ concentrations $\left(\mu \mathrm{g} \mathrm{dm}^{-3}\right)$ measured during the cruise. The black dots are the sampled depths. The white circles are the mixed layer depths. The white triangles are the depths of $1 \%$ of photosynthetically active radiation.

the MLD. The chlorophyll $a$ distribution matched that of picoeukaryotes (Fig. 9)

The vertical distribution of the heterotrophic prokaryotes at stations 5 to 12 is reported in Fig. 11. The most obvious feature is their low abundance $\left(<5 \times 10^{5}\right.$ cells cm$\left.^{-3}\right)$ in the upper $150 \mathrm{~m}$ of station 9. Conversely, high concentrations of heterotrophic prokaryotes were mainly located in the upper layer for the other stations. The two highest concentrations were observed at a depth of $50 \mathrm{~m}$ at station $7\left(1.6 \times 10^{6}\right.$ cells $\left.\mathrm{cm}^{-3}\right)$ and $112 \mathrm{~m}$ at station $11\left(2.9 \times 10^{6}\right.$ cells cm $\left.\mathrm{cm}^{-3}\right)$ where Prochlorococcus and nanoeukaryotes were particularly abundant. The relationship with autotrophs, investigated from stations 5 to 12 by calculating the integrated abundance of the heterotrophic prokaryotes to $200 \mathrm{~m}$, and looking for a correlation with the integrated chlorophyll content in the same water column (data not shown). There is no apparent correlation between the variables.

Figure 12a illustrates the contribution of each autotrophic cluster (carbon biomass integrated between the surface and $200 \mathrm{~m} \mathrm{depth}$ ) to the total autotrophic carbon biomass (sum of the biomass of the various autotrophic flow cytometry clusters). Percentages of contribution are shown for each cluster between stations 5 and 12. The contributions of Synechococcus ranged from $2.6 \%$ to $6.5 \%$ between stations 9 and 12. However, as their biomass was significantly higher between stations 5 and 8, the percentage contribution to total autotrophic carbon biomass varied from $14.1 \%$ to $21.7 \%$ (Kruskal-Wallis one-way analysis of variance, $n=7$, $p$ value $<0.05)$. The contribution of Prochlorococcus to the total autotrophic carbon biomass was lower at stations 5 and $6(13.1 \%$ and $11.7 \%$, respectively). It increased to reach a maximum at station $9(69 \%)$ and then progressively decreased to $39 \%$ at station 12 . In contrast, contribution of picoeukaryotes decreased from station $5(38 \%)$ to station 9 (5\%), and increased between stations 9 and $12(20 \%)$. The contribution of nanoeukaryotes oscillated between $33 \%$ and 


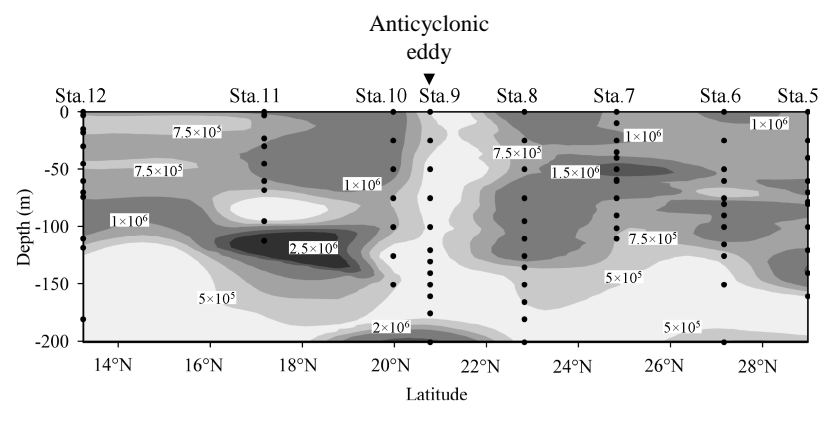

Fig. 11. Vertical concentration (cells $\mathrm{cm}^{-3}$ ) of the heterotrophic prokaryotes between stations 5 and 12. The black dots are the sampled depths.

$35 \%$ south of $20^{\circ} \mathrm{N}$, reached a minimum value of $19.7 \%$ at station 7, and increased until station $5(32.4 \%)$. The contribution of nanocyanobacteria-like was low along the transect, especially to the north of station $9(0.2 \%$, station 6$)$. The higher contribution is mainly centred between stations 9 $(0.4 \%)$ and $12(0.5 \%)$ where a peak was observed at stations 10 and 11 (6\% and $7.2 \%$, respectively). Figure 12b displays the contribution of each cluster (carbon biomass integrated between the surface and $200 \mathrm{~m}$ depth) to the sum of the biomass of the all the flow cytometry clusters. The carbon biomass of heterotrophic prokaryotes exceeded the sum of biomasses of all autotrophic clusters at stations 5 , 10,11 and $12(51.4 \%, 56.4 \%, 68.4 \%$ and $54.6 \%$, respectively). At stations 6, 7 and 8 heterotrophic prokaryotes were the main cluster with percentages ranging from $43.2 \%$ to $49 \%$. However, at station 9, the carbon biomass is dominated by Prochlorococcus (43\%) and by heterotrophic prokaryotes $(37.7 \%)$.

\subsection{Statistical analyses}

As data were collected on a large number of variables, we have applied Principal Component Analysis (PCA) to reduce the dimensions into a smaller number of principal components (linear combination of the observed variables) that account for most of the variance (Pearson, 1901). The correspondence analysis applied on the surface samples was characterised by the two first principal components which explain $41.7 \%$ and $22.9 \%$ of the total inertia, respectively (Fig. 13). The third component explains $13.9 \%$ only of the total inertia and is mostly influenced by the heterotrophic prokaryote concentration due to their high abundances compared to ultraphytoplankton. By a measure of dissimilarity between the various sets of observations, an ascendant hierarchical classification was then performed to group similar stations together. Three groups of stations were thus identified (Fig. 13). In agreement with the transition zone evidenced by the hydrographical conditions, the first group is defined by the stations south of $20.5^{\circ} \mathrm{N}$ (stations 9, 10, 11 and 12). The second group consists of two stations only (stations 7 and 8)

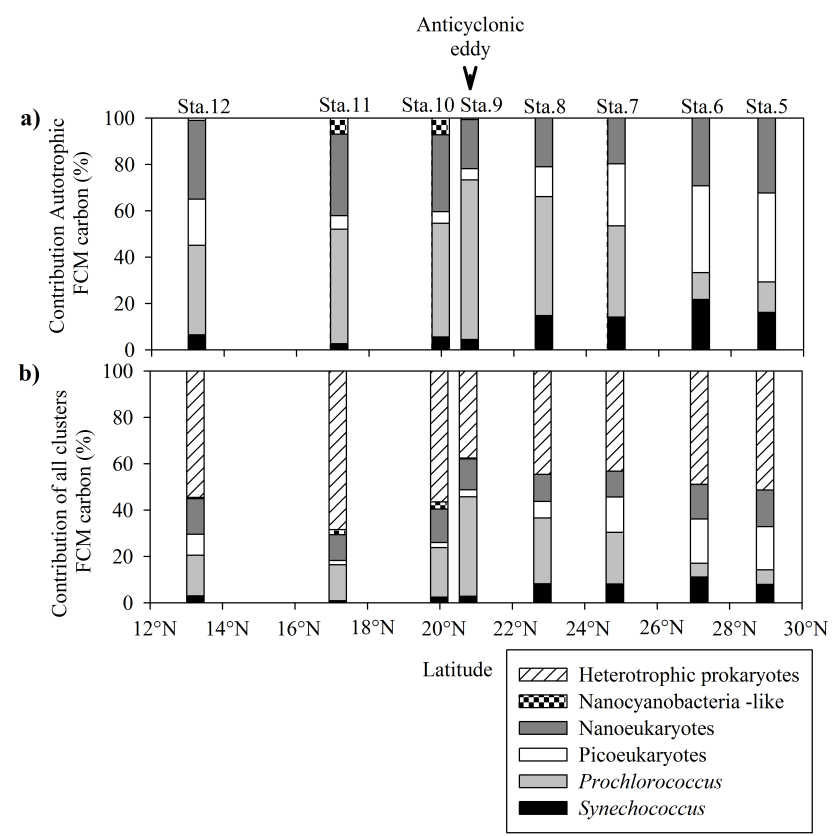

Fig. 12. Latitudinal contributions of (a) each autotrophic cluster defined by flow cytometry (FCM) to the whole autotrophic carbon biomass integrated between surface and $200 \mathrm{~m}$ depth. (b) Displays the contribution (\%) of each cluster (autotrophs and heterotrophic prokaryotes) defined by flow cytometry to the whole carbon biomass integrated between surface and $200 \mathrm{~m}$ depth.

located in the subtropical water mass. The third group contains the six stations located in the northernmost section of the transect (stations 1 to 6 ).

By using PCA, we measured the relationship between the ultraphytoplankton and the environmental variables measured. Ultraphytoplankton in the surface formed groups discriminated by their different coordinates on the two first principal components. Thus, the variable corresponding to nanocyanobacteria-like and Prochlorococcus abundance have a negative coordinate on PC1 while the variables corresponding to Synechococcus, picoeukaryote, and nanoeukaryote abundances had positive coordinates based on the circle of correlation between the variables (Fig. 13). PC1 differentiates temperature, salinity and nanocyanobacteria-like (negative coordinates) from nutrients (positive coordinates), especially nitrate and phosphate, and heterotrophic prokaryotes. Temperature and salinity were associated with the southernmost stations and contributed more to nanocyanobacterialike and Prochlorococcus distributions than to other ultraphytoplankton clusters. In contrast, the northernmost stations were characterised by the highest nutrient concentrations and their correlation with the nanoeukaryotes, picoeukaryotes, Synechococcus, and heterotrophic prokaryotes concentrations. PC2 revealed that stations 7 and 8 were associated with high abundances of Prochlorococcus, Synechococcus, and heterotrophic prokaryotes. 
a)

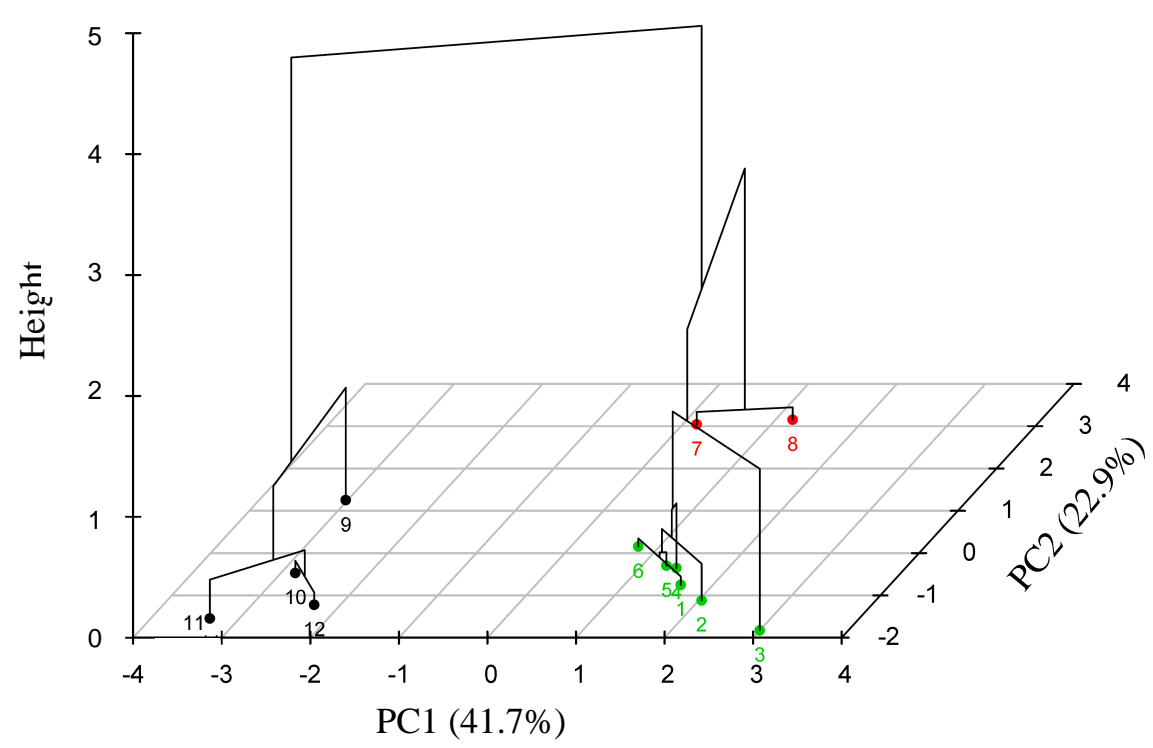

b)

$$
\text { c) }
$$
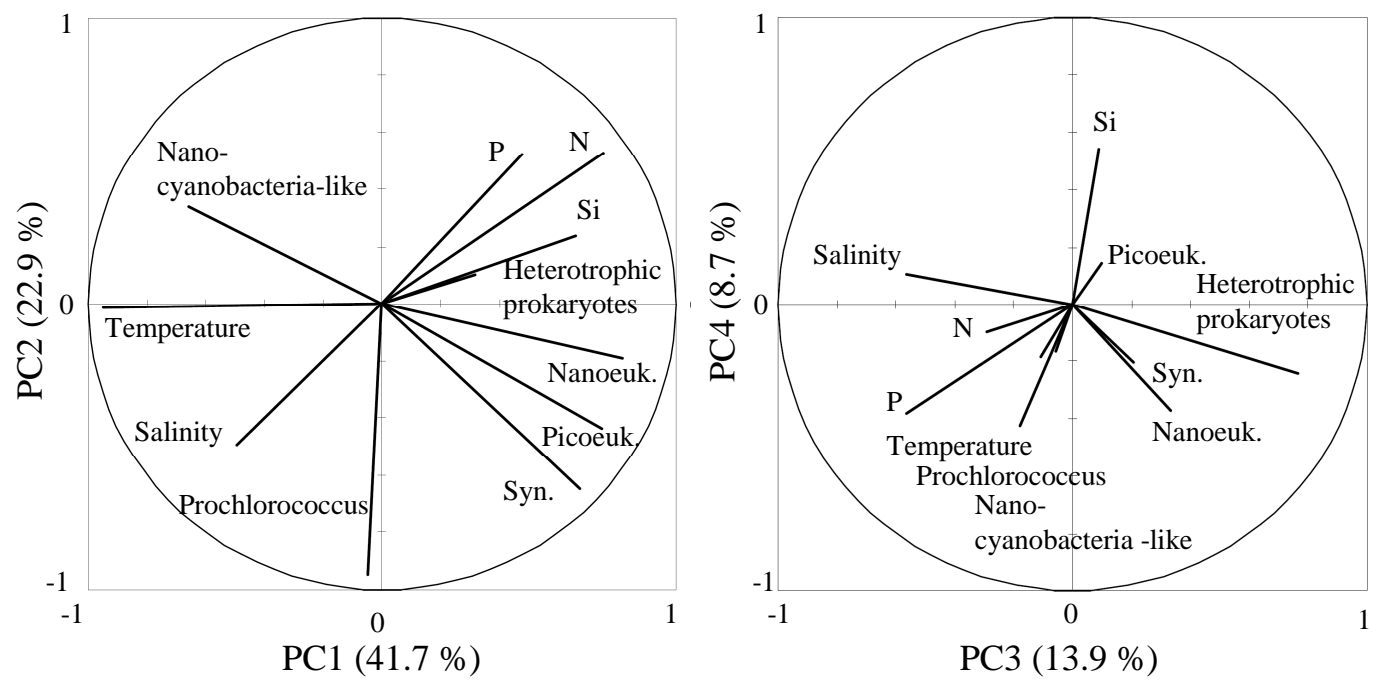

Fig. 13. Determination of the three groups of stations (1-6, 7-8, and 9-12) as identified by the hierarchical clustering (a) performed on the various parameters measured at the surface: temperature, salinity, nutrients (phosphate (P), nitrate (N) and silicic acid (Si)), the heterotrophic prokaryotes and the ultraphytoplankton (Nanocyanobacteria-like, Prochlorococcus, Synechococcus (Syn.), picoeukaryotes (Picoeuk.), Nanoeukaryotes (Nanoeuk.)). The circle (b) of correlation displays the two first dimensions of the Principal Component Analysis (PCA) and the circle (c) the dimensions 3 and 4.

The PCA and hierarchical classification applied to the data between stations 5 and 11 yielded an interesting synthesis of the environmental conditions and distribution of ultraphytoplankton (Fig. 14 and Table 1). The two first principal components explained $30.76 \%$ and $29.99 \%$ of the total inertia, respectively. With $14.1 \%$ of total inertia, PC3 mainly differentiated heterotrophic prokaryotes and nanocyanobacteria-like from the ultraphytoplanktonic groups, nutrients and salinity. PC1 mainly discriminated the environmental conditions of the microorganisms. Similarly to the PCA performed with the surface data, Prochlorococcus and nanocyanobacteria-like were separated from Synechococcus, picoeukaryotes, nanoeukaryotes, and heterotrophic prokaryotes. PC2 provides an interesting pattern due to the discrimination between temperature, salinity, and nutrients. By performing ascendant hierarchical classification, stations 5 to 11 were distributed in five clusters (Fig. 14 and Table 1). Cluster 1 characterised the sampled depths located in the deep layer where nutrients were measured in higher concentrations compared with the upper layer of the 
a)

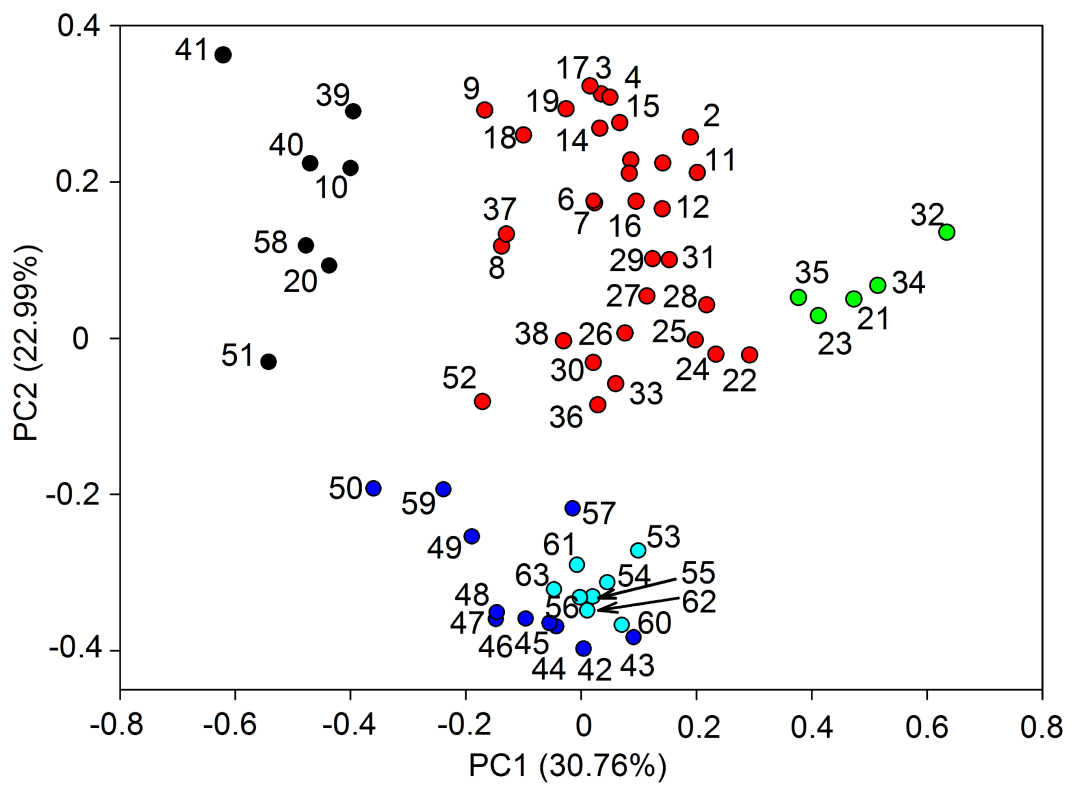

b)

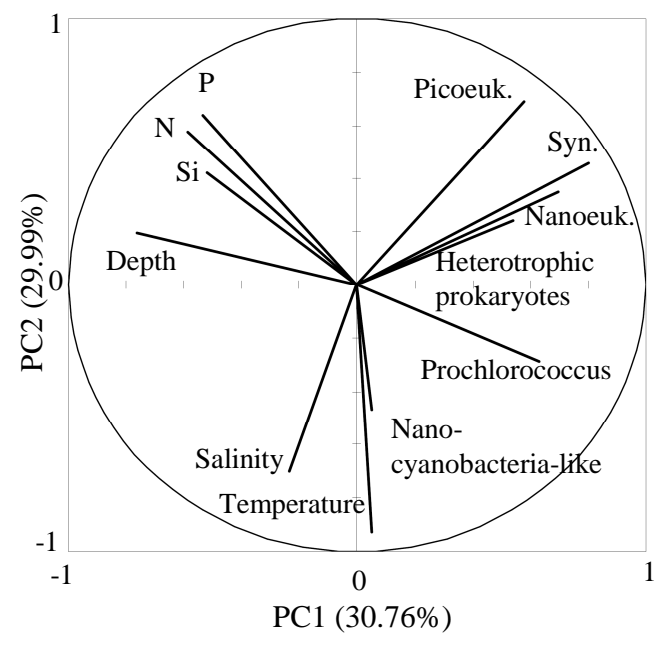

c)

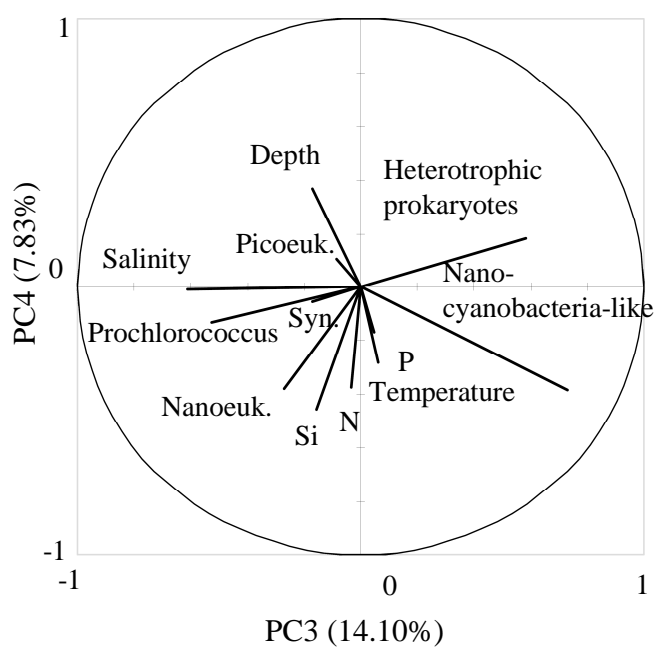

Fig. 14. Hierarchical clustering illustrated for the two first principal components of the principal component analysis performed with the data collected from stations 5 to 11 (a). According to the classification (Table 1), the sampling depths (illustrated by numbers) were separated into 5 clusters: one characterises the deep layer (Cluster 1, black), another the samples from stations 5 to 8 (Cluster 2, red), a third one the samples with a maximum of abundances (Cluster 3, green), and the two last clusters (4, blue and 5, dark blue) which characterised the southernmost stations. Cluster 5 (dark blue) focuses on station 9 where the salinity front was observed. The circle (b) displays the two first dimensions of the PCA and the circle (c) the dimensions 3 and 4.

seawater column. Cluster 2 mainly describes the northernmost stations $(75 \%$ of sampling depths collected between stations 5 and 8). Cluster 3 discriminates the sampled depths where the abundances of the enumerated organisms were maximum (station 7 at the surface and station 8 between $50 \mathrm{~m}$ and $75 \mathrm{~m}$ depths). Clusters 4 and 5 characterise the stations from the salinity front to the southernmost station $(86 \%$ of the sampling depths collected between stations 9 and 11). Cluster 4 mainly describes station 9 where the salinity front was observed and cluster 5 the station where the higher tem- perature and nanocyanobacteria-like were observed. Cluster 5 is significantly correlated with temperature and salinity (0.92 and 0.69 , respectively).

The redundancy analysis (RDA) was applied to assess the influence of the environmental variables on the phytoplankton and heterotrophic prokaryote distributions (Fig. 15). The first two axes of the RDA performed on the vertical profile data explained $49 \%$ and $33 \%$ of the total variance respectively. Monte-Carlo tests for these two first canonicals axes were highly significant ( $p<0.01$, using 999 permutations). 
Table 1. List of observations between station 5 and 11 and their classifications into five clusters according to the PCA analysis.

\begin{tabular}{lllll}
\hline $\begin{array}{l}\text { Clus- } \\
\text { ter }\end{array}$ & Observations & $\begin{array}{l}\text { Latitude } \\
\left({ }^{\circ} \mathrm{N}\right)\end{array}$ & $\begin{array}{l}\text { Sta- } \\
\text { tion }\end{array}$ & $\begin{array}{l}\text { Depth } \\
(\mathrm{m})\end{array}$ \\
\hline 1 & 10 & 28.6 & 5 & 160 \\
1 & 20 & 27.1 & 6 & 150 \\
1 & $39,40,41$ & 22.5 & 8 & $135,150,165$ \\
1 & 51 & 20.5 & 9 & 160 \\
1 & 58 & 19.6 & 10 & 125 \\
\hline 2 & $1,2,3,4,5$, & 28.6 & 5 & $0,40,60,70,78$, \\
& $6,7,8,9$ & & & $80,100,120,140$ \\
2 & $11,12,13,14,15$, & 27.1 & 6 & $0,25,60,75,80$, \\
& $16,17,18,19$ & & & $90,100,115,125$ \\
2 & $22,24,25,26,27$, & 24.5 & 7 & $10,35,40,50,59$, \\
& $28,29,30,31$ & & & $60,75,90,101$ \\
2 & $33,36,37,38$ & 22.5 & 8 & $25,95,110,125$ \\
2 & 52 & 20.5 & 9 & 200 \\
\hline 3 & 21,23 & 24.5 & 7 & 0,25 \\
3 & $32,34,35$ & 22.5 & 8 & $0,50,75$ \\
\hline 4 & $42,43,44,45,46$, & 20.5 & 9 & $0,25,50,75,100$, \\
& $47,48,49,50$ & & & $120,130,140,150$ \\
4 & 57,59 & 19.6 & 10 & 100,150 \\
\hline 5 & $53,54,55,56$ & 19.6 & 10 & $0,25,50,75$ \\
5 & $60,61,62,63$ & 17.18 & 11 & $0,30,45,60$ \\
\hline
\end{tabular}

The sums of all canonical eigenvalues indicated that $93 \%$ of the observed planktonic cluster variation were explained by the environmental variables. The first axe is negatively correlated with temperature and salinity representing the mesoscale circulation. The second axe is negatively correlated with nutrient concentrations which represent the different conditions between the samples collected at surface or deeper in the water column.

Partial redundancy analysis (partial RDA) was also applied to the profile dataset to estimate the effects of each environmental variable on the various ultraplanktonic clusters. Among the six environmental variables measured during the cruise, temperature and salinity statistically contribute for $28.9 \%$ and $19.2 \%$ of the variation in the composition of phytoplankton and heterotrophic prokaryotes, respectively. The sample depth solely explained $8.3 \%$ whereas nitrate, silicic acid and phosphate explained $4.3 \%, 3.6 \%$ and $2 \%$, respectively.

\section{Discussion}

\subsection{Spatial distribution of seawater masses in a complex system}

This study differentiates the western part of the NPSG into three regions on the basis of the water mass properties (temperature and salinity) and environmental conditions (nutrients and ultraphytoplankton abundances).

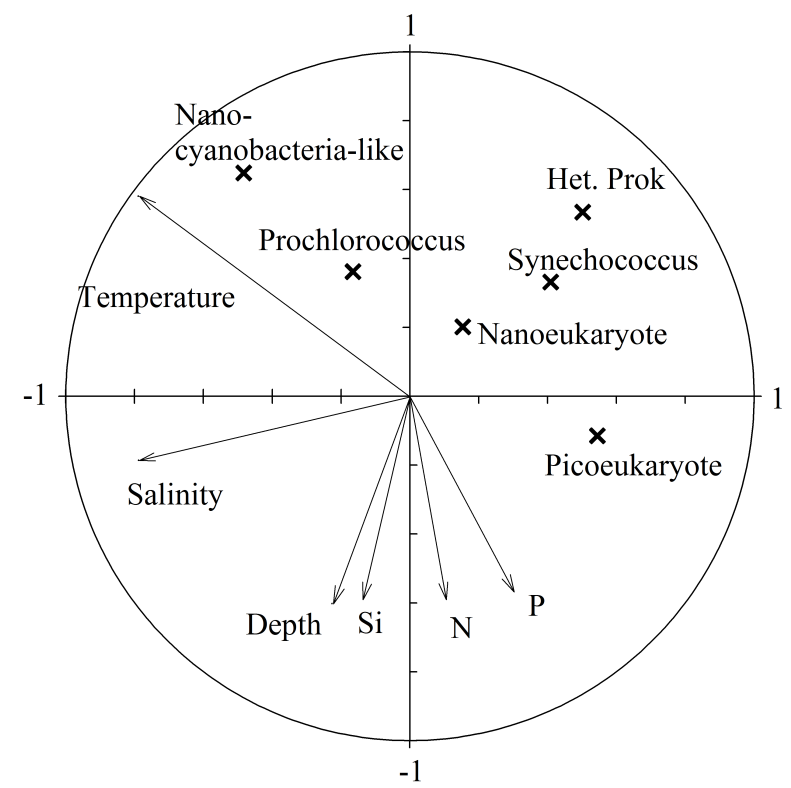

Fig. 15. Correlation plot of the redundancy analysis (RDA) on the relationships between the environmental variables and the prokaryote and ultraphytoplankton composition determined by flow cytometry.

The stations located in the Kuroshio region were characterised by important abundances of ultraphytoplankton supported by the highest concentrations of nutrients measured at the surface.

According to the Tomczak and Godfrey study, the subtropical gyre water mass was identified by stations 5 to 8 between $28.98^{\circ} \mathrm{N}$ and $22.83^{\circ} \mathrm{N}$ (Tomczak and Godfrey, 1994). This group of stations was isolated between the thermal front of the Kuroshio Current and the salinity front observed to the south of station 8 . Similar salinity fronts have been previously reported in the literature between $25.3^{\circ} \mathrm{N}$ and $22.8^{\circ} \mathrm{N}$ (Kitajima et al., 2009). This salinity front was demonstrated to be linked to the difference between the centre of the subtropical Pacific gyre water mass and the North Equatorial Current (NEC) (Tomczak and Godfrey, 1994). The salinity front observed around $22.83^{\circ} \mathrm{N}$ appears to be a complex phenomenon induced by the mixing of different seawater masses. Several structures such as eddies can be observed between $20^{\circ} \mathrm{N}$ and $25^{\circ} \mathrm{N}$ (Fig. 1). This mesoscale circulation $(75 \mathrm{~km})$ illustrates the complex distribution of seawater masses, as previously reported in the literature (Qiu, 1999; Aoki et al., 2002).

The temperature-salinity diagram highlights this pattern in the upper layer with different profiles between stations 7 and 8 (Fig. 5). Separation of these profiles can be in part caused by excessive evaporation which increased the salinity in the upper layer of station 7. Evaporation mechanism was indeed reported to drastically modify the salinity, especially in the centre of the Pacific subtropical gyre (Kimura 
et al., 2001). Due to the sparse information available in the literature, the notable lower salinity measured at station 8 between $100 \mathrm{~m}$ and $130 \mathrm{~m}$ depths remains difficult to link to a particular seawater mass. However, several studies reported a slightly lower salinity in the upper layer around $21^{\circ} \mathrm{N}(\mathrm{Ki}-$ tajima et al., 2009; Xie et al., 2009). In the present study, the lower salinity recorded in the subsurface layer can be explained in part by the vicinity of the subtropical front (STF). According to the investigation of Aoki et al. (2002), the STF is usually associated with the shallow eastward subtropical counter current (STCC). Several theories listed in Kobashi et al. (2006) try to explain the formation of the STCC, including wind stress, heat flux, Rossby waves, potential vorticity and subtropical mode water. Although subtropical mode water has the same salinity as station 8 (34.71 to 34.77 ; Oka, 2009), higher temperatures measured during this cruise do not match with the water mass properties measured between $100 \mathrm{~m}$ and $130 \mathrm{~m}$ depths. The core of the STCC was reported to have a potential density $\sigma_{\mathrm{O}}=24.5$ at $23^{\circ} \mathrm{N}$ and $138.5^{\circ} \mathrm{E}$ (Chu et al., 2002). These values may indicate that the STCC core was deeper than in this study. However, Kimura et al. (2001) previously showed that salinity and temperature anomalies were negative and positive, respectively at $22^{\circ} \mathrm{N}$ during La Niña event. Therefore, this result suggests that under the La Niña condition, the density, as measured during the cruise, is slightly lower than the average STCC property. This difference in salinity (about 0.05 ) could identify the core of the STCC and explain the specific profile measured at station 8.

In the second group of stations, nutrients were depleted in the upper layer, especially in the area south of station 6 , where nutrient concentrations were near the detection limit. Despite the oligotrophic conditions, a higher abundance of ultraphytoplankton was found in the second group of stations with a maximum at station 8 . This maximum was located just upper the low salinity record identified as the STCC and was related to the higher nutrient concentrations.

Due to the temperature being lower than $28.5^{\circ} \mathrm{C}$ the third group of stations (stations 9 to 12) is referred in this study as a transition zone between the Warm pool and the subtropical gyre (Cravatte et al., 2009). This transition zone was characterised by a large gradient in salinity and temperature between surface and $200 \mathrm{~m}$ depth. Similarly to the previous group of stations, the nutrient concentrations were depleted in the upper layer. However, cell concentrations were the lowest of the transect. The transition zone was marked by the boundary in term of temperature and salinity between stations 8 and 9 . From station 9 a clear decrease in salinity was observed in the layer above the thermocline. This lower salinity was usually observed in the upper layer because precipitation minus annual average net evaporation was positive in this area (Lukas and Lindstrom, 1991). Between $100 \mathrm{~m}$ and $200 \mathrm{~m}$ depths the observed increase of salinity characterised the North Pacific tropical water (NPTW; Kimura et al., 2001).

\subsection{Distribution of ultraphytoplankton assemblages and latitude}

This study revealed an obvious variability in the abundance of ultraphytoplankton assemblages depending on latitude. This spatial variability confirmed that the constant oligotrophic conditions may lead to the high variability in phytoplankton assemblage (Marañon et al., 2003). Spatial distribution of the dominant group of ultraphytoplankton, Prochlorococcus, usually paralleled the vertical distribution of chlorophyll $a$ concentrations measured between the surface and $200 \mathrm{~m}$ depth (Figs. 9b and 10). The vertical distribution of Prochlorococcus tends to differ from Synechococcus in the NEC. South of $20^{\circ} \mathrm{N}$, the Prochlorococcus maximum was located in the NPTW layer where it induced a pronounced subsurface chlorophyll $a$ maximum (Fig. 10). Accumulation of organisms such as heterotrophic prokaryotes and Prochlorococcus might be favoured by the halocline. This pattern of vertical distribution (low abundance at surface and a peak in the subsurface layer) was previously observed in the Sargasso Sea in summer and described as type 2 (Olson et al., 1990; Suzuki et al., 1995).

In the literature, Prochlorococcus are basically linked to stratified nutrient-depleted waters and several studies have mentioned that Prochlorococcus are absent in high latitude due to the low temperature and salinity (Campbell and Vaulot, 1993; Moore et al., 1995; Obayashi et al., 2001). Recently, significant relationships between Prochlorococcus and other autotrophic and heterotrophic clusters have indicated this segregation (Zhang et al., 2008). Results of the PCA and RDA confirmed this trend and suggest that the Prochlorococcus distribution is more positively correlated to temperature and salinity than the other picophytoplankton clusters, both in surface and in the deep layer waters (Figs. 13, 14 and 15). At station 9 in particular, the highest salinity measured in the upper layer coincided with the maximum abundance of Prochlorococcus. The distribution of Prochlorococcus in the upper layer of this station was homogenous between the surface and down to $120 \mathrm{~m}$. This type of profile observed only once during the cruise was described as type 3 in the literature and was previously reported to be most widespread between $30^{\circ} \mathrm{N}$ and $30^{\circ} \mathrm{S}$ (Suzuki et al., 1995; Partensky et al., 1999).

In oligotrophic conditions the primary production is usually described to be linked to the regeneration of organic matter via microbial processes (Karl, 1999; Fernandez et al., 2008). Karl (1999) reported that regenerated primary production in the NPSG is 10 to 20 times greater than the new primary production. In order to identify a possible relationship between the autotrophic organisms and the heterotrophic prokaryotes, we integrated the chlorophyll $a$ concentration and the abundance of heterotrophic prokaryotes from the surface down to $200 \mathrm{~m}$ depth (data not shown): results revealed no clear relationship between these two parameters as previously observed in other areas (Painchaud 
and Therriault, 1989). However, according to the Thyssen et al. (2005) results, a positive relationship was found between the heterotrophic prokaryotes with a high nucleic acid content (HNA) and chlorophyll $a$ concentration.

The spatial distribution of Synechococcus in the Transition zone was mostly located above the maxima of Prochlorococcus and picoeukaryote abundances. Although surface Prochlorococcus cannot be accurately enumerated by flow cytometry due to their dim fluorescence (due to low pigment content in response to the strong irradiation), our results are consistent with the classical pattern and physiological properties of these microorganisms (Zhang et al., 2008; Mella-Flores et al., 2012). Mella-Flores et al. (2012) described that in contrast to Prochlorococcus, Synechococcus have developed efficient mechanisms to cope with strong light such as in the surface layer. Similarly, Synechococcus were shown to have several advantages both in terms of nitrate and phosphate uptake in depleted nutrient conditions (Rippka et al., 2000; Moutin et al., 2002; Michelou et al., 2011). In the subtropical gyre water mass, phosphate depleted concentrations $(<10 \mathrm{nM})$ at the surface were expected to control the microorganism distributions (Kitajima et al., 2009). From stations 5 to 8, in contrast to other communities, the Synechococcus abundance highlighted its capacity to successfully compete Prochlorococcus in nutrient depleted conditions (PCA results). Kitajima et al. (2009) reported similar increase in Synechococcus abundance in the north of $20^{\circ} \mathrm{N}$. They related the dominance by nanophytoplankton cyanobacteria and Synechococcus to diazotrophy. This ability of some Synechococcus strains to fix a new source of nitrogen (dissolved $\mathrm{N}_{2}$ ) combined with the significant nitrogen uptake from organic compounds reported by Michelou (2009) can lead to a different gradient in abundance of species and in carbon biomass in this area, with consequences on the biological pump efficiency.

The fixation of dissolved $\mathrm{N}_{2}$ is an important ability of some nanocyanobacteria to survive in both nitrate and phosphate depleted environments (Zehr et al., 2001). Observations of nanocyanobacteria-like in the upper layer confirm previous investigations in the subtropical Pacific gyre (Sato et al., 2010). Although the concentrations of nanocyanobacteria-like are in the range of the abundances measured (Fig. 9e), latitudinal distribution of organisms enumerated in this study differed from the observations of Kitajima et al. (2009) and Sato et al. (2010). In the NPSG, Kitajima et al. (2009) suggested that exhaustion of phosphate at the surface is linked to a high concentration of nanocyanobacteria. However, Sato et al. (2010) suggested an opposite relationship between the high abundance of nanocyanobacteria and phosphate-replete conditions in the NPSG. On the basis of the study of Hashihama et al. (2009), Sato et al. (2010) reported that nanocyanobacteria abundance can not be linked to a front as referred from salinity or temperature in the NPSG. In this study, we observed that the concentration of phosphate is very low (nanomolar level) in the upper layer from station 7 to station 11, but the abundance of nanocyanobacteria-like is mainly located southward of station 9. Therefore, the concentrations of nanocyanobacterialike did not coincide with the phosphate concentrations, but clearly coincided with the front of salinity observed at station 9. PCA and RDA performed on data collected both at the surface and along the vertical profiles (Figs. 13, 14 and 15 , respectively) tend to statistically confirm the correlation between the salinity front, high temperature condition and high concentration of nanocyanobacteria-like. This result is in agreement with Church et al. (2008) who reported that frontal system can control the distributions of $\mathrm{N}_{2}$-fixing marine microbes in the NPSG.

\subsection{Distribution of ultraphytoplankton assemblages and eddies}

Along the transect studied during this cruise, several complex hydrographical structures such as eddies were observed and the relationship with the distribution of ultraphytoplankton was investigated. In the vicinity of the anticyclonic eddy A, the contribution of autotrophic clusters to the carbon biomass integrated between 0 and $200 \mathrm{~m}$ revealed that nanocyanobacteria-like and picoeukaryotes at station 9 were the less important contributors (Fig. 12). Both in terms of carbon biomass and abundance, this station was dominated by Prochlorococcus. Ultraphytoplankton community numerically dominated by Prochlorococcus has usually been reported in anticyclonic eddies sampled in the Northern Hemisphere (Fernandez et al., 2008; Peterson et al., 2011). Using the hierarchical classification, the discrimination of the sampling depths suggested that the anticyclonic eddy has lead to a modification of nutrient conditions in the water column. Low concentration of nutrients may suggest that the ecosystem can be supported by a microbial loop (regenerated production) in the upper layer (Selmer et al., 1993). Consequently, high abundance of heterotrophic prokaryotes is expected in the epipelagic zone as previously reported in some anticyclonic eddies (Lasternas et al., 2013). Surprisingly, the lowest abundance of the heterotrophic prokaryotes in the upper layer was found at station 9 and does not seem to be linked to the chlorophyll $a$ concentration (Fig. 11). Although previous investigations on the microbial community reported that high abundance of heterotrophic bacteria in the anticyclonic eddies can be explained by the senescence of the phytoplankton communities, Baltar et al. (2010) found significantly lower prokaryotic activity in the anticyclonic eddy than outside. Similarly, Lasternas et al. (2013) reported lower heterotrophic bacteria viability in the anticyclonic eddy despite a high release of dissolved organic carbon produced by cell lysis. Consequently, they suggested that limitation by inorganic nutrients such as phosphate can modify the viability of heterotrophic bacteria at anticyclonic eddies. Low values of $\mathrm{N}: \mathrm{P}$ in the upper layer associated with the higher $\mathrm{Si}: \mathrm{P}$ ratios were found at station 9. Although nutrients were at 
nanomolar level in the surface layer of station 9 , these values suggested that phosphate concentration is particularly low by comparison with the nutrient concentrations measured at other stations. Low concentrations of phosphate and nitrate associated with a deep thermocline may lead to the specific distribution of heterotrophic prokaryotes at anticyclonic eddy A.

In contrast, the cyclonic eddy $\mathrm{C}$ identified at the station 3 in the Kuroshio region tends to improve the nutrient conditions at surface. The nutrient enhancement, especially in nitrate and phosphate, coincided with a maximum of nanoeukaryotes. At the mesoscale level, the upward transport of water is reported to modify the composition of phytoplankton communities in various environments (Fernandez et al., 2008; Rii et al., 2008). In the NPSG area, Rii et al. (2008) reported a slight increase of nanoeukaryote abundance in the periphery of the eddy. Similarly a previous study in the central Pacific Ocean showed that large phytoplankton groups were more abundant inside the cyclonic eddy than outside (Vaillancourt et al., 2003). During the Tokyo Palau cruise, results of microphytoplankton assemblages revealed that the highest abundance of diatoms was observed at station 3 (Girault et al., 2013). Girault et al. (2013) pointed out that several species, mainly diatoms, usually reported to live at the SCM were identified at the surface. These cells seem to partially use the dissolved organic phosphorus contrasting to other cells described to live in the surface layer. Difference in utilisation of dissolved organic phosphorus at the surface coupled with the thermocline dome suggested that the cold core cyclonic eddy at station 3 enhanced the phosphorus condition at the surface. The lowest value of the $\mathrm{Si}$ : $\mathrm{P}$ ratio calculated in the Kuroshio suggested that silica (here silicic acid) is particularly used at surface of the cyclonic gyre (Fig. 7). Low $\mathrm{Si}$ : $\mathrm{P}$ ratio can result in the utilisation of the silicic acid by diatoms in the upper layer. The dominance by large phytoplanktonic cells (nano- and microphytoplankton) were in agreement with previous observations which revealed that communities made of large phytoplankton are indeed usually promoted by the nutrient inputs in the cold core of cyclonic eddy (Vaillancourt et al., 2003).

\subsection{Variability of ultraphytoplankton abundances depending on the ENSO}

Previous investigations focussing on the distribution of picophytoplankton in the western part of NPSG were mainly conducted under the El Niño conditions (Shimada et al., 1993; Horimoto et al., 2001; Kitajima et al., 2009). To the best of our knowledge this study during the Tokyo Palau cruise is the first report investigating the ultraphytoplankton assemblages under marked La Niña conditions (Fig. 2). While we recognise that this study focused on a single transect in January and cannot be representative of the La Niña condition in the whole Pacific, interesting results have emerged. Despite the seasonal variability in abundance of phytoplank- ton reported in the subtropical water (Steinberg et al., 2001), concentrations of ultraphytoplankton measured in our study are higher in the centre of the subtropical gyre than observations reported in the same area. For instance the concentrations of Synechococcus were lower than $1 \times 10^{4}$ cells cm$^{-3}$ in the subtropical area both in the studies of Shimada et al. (1993) (August-September, November-December), Horimoto et al. (2001) (March) and Kitajima et al. (2009) (November-December and May-June). These concentrations were about a factor of 10 times lower than our results. In contrast, the concentrations of Synechococcus measured in the Kuroshio region were obviously higher than our results. By using a fluorescent microscope method, Horimoto et al. (2001) reported a concentration of Synechococcus higher than $3 \times 10^{5}$ cells cm$^{-3}$ (October), and $2 \times 10^{5}$ cells cm$^{-3}$ (June) at the surface of the Kuroshio Current. Similar high Synechococcus concentrations from $29.8^{\circ} \mathrm{N}$ to the northernmost stations were reported in the study of Kitajima et al. (2009) (November-December and May-June). This difference was also in agreement with the study conducted along the $175^{\circ} \mathrm{E}$ transects in 1992 and 1993 during the strong El Niño events (Suzuki et al., 1997). In their study, they noticed that a change in ultraphytoplankton abundance was characterised by high concentrations of Prochlorococcus rather than Synechococcus which were reported to be insignificant by comparison with the chlorophyll $a$ concentrations. In the open ocean, modifications in ultraphytoplankton communities are usually suggested to be linked to nutrient concentrations (Karl et al., 2001; Matsumoto et al., 2004; Matsumoto and Furuya, 2011). Although nutrient concentrations at the surface were similar than the El Niño conditions, Fig. 6 shows some patches of higher concentration of nutrients at the station 8 and north to station 6 (Kitajima et al., 2009; Hashihama et al., 2009). A possible explanation of these various ultraphytoplankton concentrations may be related to the variability in Ocean structures characterised by the El Niño and La Niña conditions. Contrasting conditions in the Ocean structures and phytoplankton distributions can be enhanced by the strength of the NEC along the Equator. In the western part of the Pacific subtropical gyre the NEC bifurcates into Kuroshio Current (northward flowing) and the Mindanao Current (southward flowing) along the Philippine coast. The location of the bifurcation was suggested to vary depending on several factors including local monsoons and remote Rossby waves (Qiu and Lukas, 1996). However, bifurcation is also expected to vary seasonally and interannually in agreement with the ENSO value (Kim et al., 2004). Consequently, Kashino et al. (2009) reported that bifurcation depending on the ENSO is an important mechanism able to modify the transport of the Kuroshio Current at higher latitudes. Due to the high correlation between the NEC and the Kuroshio transport Kim et al. (2004) suggested that one part of the ENSO signal of the NEC penetrates into the mid-latitude circulation through the Kuroshio Current. In the present study, the ENSO index (Fig. 2) shows that 
sampling experiments were conducted during a cold phase of ENSO (La Niña). During La Niña, the bifurcation of the NEC is usually estimated to be located at lower latitudes and the Kuroshio transport is stronger than under the El Niño conditions (Kashino et al., 2009). The subtropical seawater mass surrounded by the NEC and the Kuroshio Current also shows an interannual variability in the structure especially via the STCC and the production of the mesoscale eddies (White et al., 1978; Qiu and Chen, 2010; Chang and Oey, 2011). This spatial heterogeneity into seawater structures was observed during the cruise. Along the transect two eddies were found and a marked salinity front close to the STCC put in evidence as well. In these conditions our results suggest that the distribution of ultraphytoplankton communities under La Niña conditions was different than in previous reports under El Niño conditions both in the Subtropical gyre seawater mass and Kuroshio region. Spatial heterogeneity of the seawater masses associated with the ENSO may lead to contrasting trends in the phytoplankton abundances as recently reported with satellite assessment and mathematical models (Masotti et al., 2011; Rousseaux and Gregg, 2012). Although this study was conducted under a notable climatic event, this study was conducted on a single transect only, in January. To address the role of La Niña in the distribution of ultraphytoplankton and confirm our preliminary results, complementary investigations at various locations and different periods should be conducted during another La Niña conditions.

\section{Conclusions}

The results presented in this study show that the heterogeneous distribution of phytoplankton communities is associated with the complex distribution of various seawater masses in the western part of the NPSG. During the cruise, three different types of seawater masses have been identified and two eddies were observed between $33.6^{\circ} \mathrm{N}$ and $13.25^{\circ} \mathrm{N}$. Along the transect covered during the cruise, Prochlorococcus outnumbered the other autotrophic clusters and were usually associated with stratified oligotrophic areas. However, nanoeukaryotes, picoeukaryotes, and Synechococcus constituted a significant part of the carbon biomass in regions depleted in phosphate and nitrate. Dominance by nanoeukaryotes, picoeukaryotes, and Synechococcus was in relation with the more efficient nutrient uptakes than Prochlorococcus in depleted conditions. However, the nanocyanobacteria-like distribution seems not to be mainly controlled by the nutrient concentrations but rather by the frontal system observed at the $22.83^{\circ} \mathrm{N}$. During the cruise, the maximum abundance of ultraphytoplankton was observed close to the salinity front and just above the centre of the STCC. During La Niña events, the vicinity of the subsurface chlorophyll $a$ maximum with the STCC suggested that the current enhances the nutrient conditions in oligotrophic ecosystem and therefore improves the growth of the microorganisms and thus the functioning of the biological pump.

Acknowledgements. We thank Captain Akira Noda, crew members, and scientists of the RT/V Shinyo Maru of Tokyo University of Marine Science and Technology, (TUMSAT) for their cooperation at sea. We are grateful to Yuta Nakagawa for his help during the cruise. We are also grateful to the Mediterranean Institute of Oceanography (MIO) for its support and to the PRECYM flow Cytometry Platform (MIO) for the flow cytometry analyses. We thank Michel Denis and Melilotus Thyssen for their helpful comments on the manuscript, and Claude Manté and Bastien Mérigot for helpful advices in statistics. We thank the Société franco-japonaise d'Océanographie for its support to ship the samples from Japan to France. We also thank Chris Norman for the proofreading.

Edited by: E. Marañón

\section{References}

Aoki, Y., Suga, T., and Hanawa, K.: Subsurface subtropical fronts of the North Pacific as inherent boundaries in the ventilated thermocline, J. Phys. Oceanogr., 32, 2299-2311, 2002.

Baltar, F., Aristegui, J., Gasol, J. M., Lekunberri, I., and Herndl, G. J.: Mesoscale eddies: 10 hotspots of prokaryotic activity and differential community structure in the ocean, ISME J., 4, 975988, 2010.

Blanchot, J., Andre, J. M., Navarette, C., Neveux, J., and Radenac, M. H.: Picophytoplankton in the equatorial Pacific: vertical distributions in the warm pool and in the high nutrient low chlorophyll conditions, Deep-Sea Res. I, 48, 297-314, 2001.

Brzezinski, M. A.: The Si:C:N ratio of marine diatoms: interspecific variability and the effect of some environmental variables, J. Phycol., 21, 347-357, 1985.

Cailliau, C., Claustre, H., Vidussi F., Marie, D., and Vaulot, D.: Carbon biomass, and gross grotwth trates as estimates from C-14 pigment labelling, during photoacclimation in prochlorococcus CCMP 1378, Mar. Ecol.-Prog. Ser., 145, 209-221, 1996.

Campbell, J. W. and Yentsch, C. M.: Variance within homogeneous phytoplakton populations. 1 Theoritical framework for interpreting histograms, Cytometry, 10, 587-595, 1989.

Campbell, L. and Vaulot, D.: Photosynthetic picoplankton community structure in the subtropical North Pacific Ocean near Hawaii (Station ALOHA), Deep-Sea Res. I, 40, 2043-2060, 1993.

Campbell, L., Liu, H., Nolla, H. A., and Vaulot, D.: Annual variability of phytoplankton and bacteria in the subtropical North Pacific Ocean at the station ALOHA during the 1991-1994 ENSO event, Deep-Sea Res. I, 44, 167-192, 1997.

Caron, D. A., Dam, H. G., Kremer, P., Lessard, E. J., Madin, L. P., Malone, T. C., Napp, J. M., Peele, E. R., Roman, M. R., and Youngbluth, M. J.: The contribution of microorganisms to particulate carbon and nitrogen in surface waters of the Sargasso Sea near Bermuda, Deep-Sea Res. I, 42, 943-972, 1995.

Chang, Y. L. and Oey L. Y.: Interannual and seasonal variations of Kuroshio transport east of Taiwan inferred from 29 years of tide-gauge data, Geophys. Res. Lett., 38, L08603, doi:10.1029/2011GL047062, 2011. 
Chu, P. C., Li, R., and You, X.: Northwest Pacific subtropical countercurrent on isopycnal surface in summer, Geophys. Res. Lett., 29, 1842, doi:10.1029/2002GL014831, 2002.

Church, M. J., Bjorkman, K. M., Karl, D. M., Saito, M. A., and Zehr J. P.: Regional distribution of nitrogen-fixing bacteria in the Pacific Ocean, Limnol. Oceanogr., 53, 63-77, 2008.

Cravatte, S., Delcroix, T., Zhang, D., McPhaden, M., and Leloup, J.: Observed freshening and warming of the western Pacific Warm Pool, Clim. Dynam., 33, 565-589, 2009.

Fernandez, C., Thyssen, M., and Denis, M.: Microbial community structure along $18^{\circ} \mathrm{W}\left(39^{\circ} \mathrm{N}-44.5^{\circ} \mathrm{N}\right)$ in the NE Atlantic in late summer 2001 (POMME Programme), J. Mar. Syst., 71, 46-62, 2008.

Garside, C.: A chemiluminescent technique for the determination of nanomolar concentrations of nitrate and nitrite in seawater, Mar. Chem., 11, 159-167, 1982.

Girault, M., Arakawa, H., and Hashihama, F.: Phosphorus stress of microphytoplankton community in the western subtropical North Pacific, J. Plankton Res., 35, 146-157, 2013.

Goericke, R. and Montoya, J. P.: Estimating the contribution of microalga taxa to chlorophyll $a$ in the field-variations of pigment ratios under nutrient- and light-limited growth, Mar. Ecol.-Prog. Ser., 169, 97-112, 1998.

Gregori, G., Denis, M., Sgorbati, S., and Citterio, S.: Resolution of viable and membrane-compromised free bacteria in aquatic environments by flow cytometry, in: Curr. Protoc. Cytom., Chapter 11, Unit 11.15, doi:10.1002/0471142956.cy1115s23, 2003.

Hashihama, F. and Kanda, J.: Automated colorimetric determination of trace silicic acid in seawater by gas-segmented continuous flow analysis with a liquid waveguide capillary cell, La Mer, 47, 119-127, 2010.

Hashihama, F., Furuya, K., Kitajima, S., Takeda, S., Takemura, T., and Kanda, J.: Macro-scale exhaustion of surface phosphate by dinitrogen fixation in the western North Pacific, Geophys. Res. Lett., 36, L03610, doi:10.1029/2008GL036866, 2009.

Henriksen, P., Riemann, B., Kaas, H., Sorensen, H. M., and Sorensen, H. L.: Effects of nutrient-limitation and irradiance on marine phytoplankton pigments, J. Plankton Res., 24, 835-858, 2002.

Horimoto, N., Yamaguchi, Y., and Ishimaru, T.: The distribution of picophytoplankton across Kuroshio Current off the western Pacific coast of Japan, La Mer, 39, 181-195, 2001.

Kana, T. M. and Glibert, P. M.: Effect of irradiances up to $2000 \mu \mathrm{Em}^{-2} \mathrm{~s}^{-1}$ on marine Synechococcus WH7803. 1. Growth, Pigmentation, and cell composition, Deep-Sea Res., 34, 479-495, 1987.

Kashino, Y., España, N., Syamsudin, F., Richards, K. J., Jensen, T., Dutrieux, P., and Ishida, A.: Observations on the North equatorial current, Mindanao current, and Kuroshio current system during the 2006/07 El Niño and 2007/08 La Niña, J. Oceanogr., 65, 325333, 2009.

Karayanni, H., Christaki, U., Van Wambeke, F., Denis, M., and Moutin, T.: Influence of ciliated protozoa and heterotrophic nanoflagellates on the fate of primary production in the northeast Atlantic Ocean, J. Geophys. Res., 110, C07S15, doi:10.1029/2004JC002602, 2005.

Karl, D. M.: A sea of change: biogeochemical variability in the North Pacific Subtropical Gyre, Ecosystems, 2, 181-214, 1999.
Karl, D. M. and Tien, G.: MAGIC: A sensitive and precise method for measuring dissolved phosphorus in aquatic environments, Limnol. Oceanogr., 37, 105-116, 1992.

Karl, D. M., Bidigare, R. R., and Letelier, R. M.: Long term changes in plankton community structure and productivity in the North Pacific Subtropical Gyre: The domain shift hypothesis, Deep-Sea Res. II, 48, 1449-1470, 2001.

Kim, Y. Y., Qu, T., Jensen, T., Miyama, T., Mitsudera, H., Kang, H.-W., and Ishida, A.: Seasonal and interannual variations of the North Equatorial Current bifurcation in a high-resolution OGCM, J. Geophys. Res., 109, C0350, doi:10.1029/2003JC002013, 2004.

Kimura, S., Inoue, T., and Sugimoto, T.: Fluctuation in the distribution of low-salinity water in the North Equatorial Current and its effect on the larval transport of the Japanese eel, Fish. Oceanogr., 10, 51-60, 2001.

Kitajima, S., Furuya, K., Hashihama, F., Takeda, S., and Kanda, J.: Latitudinal distribution of diazotrophs and their nitrogen fixation in the tropical and subtropical western North Pacific, Limnol. Oceanogr., 54, 537-547, 2009.

Kobashi, F., Mitsudera, H., and Xie, S. P.: Three subtropical fronts in the North Pacific: Observational evidence for mode water-induced subsurface frontogenesis. J. Geophys. Res., 111, C09033, doi:10.1029/2006JC003479, 2006.

Lasternas, S., Piedeleu, M., Sangrà, P., Duarte, C. M., and Agustí, S.: Forcing of dissolved organic carbon release by phytoplankton by anticyclonic mesoscale eddies in the subtropical NE Atlantic Ocean, Biogeosciences, 10, 2129-2143, doi:10.5194/bg10-2129-2013, 2013.

Lebaron, P., Parthuisot, N., and Catala, P.: Comparison of blue nucleic acid dyes for flow cytometric enumeration of bacteria in aquatic systems, Appl. Environ. Microbiol., 64, 1725-1730, 1998.

Li, B., Karl, D. M., Letelier, R. M., and Church, M. J.: Sizedependent photosynthetic variability in the North Pacific Subtropical Gyre, Mar. Ecol.-Prog. Ser., 440, 27-40, 2011.

Lipkovich, L. I. and Smith, E. P.: Biplot and singular value decomposition macros for Excel $^{\circledR}$, J. Stat. Softw., 7, 1-15, 2002.

Liu, Q.: Variation partitioning by partial redundancy analysis (RDA), Environmetrics, 8, 75-85, 1997.

Lukas, R. and Lindstrom, E.: The mixed layer of the western Equatorial Pacific Ocean, J. Geophys. Res., 96, 3343-3357, 1991.

Marañon, E., Behrenfeld, M. J., González, N., Mouriño, B., and Zubkov, M. V.: High variability of primary production in oligotrophic waters of the Atlantic Ocean: uncoupling from phytoplankton biomass and size structure, Mar. Ecol.-Prog. Ser., 257, $1-11,2003$.

Marie, D., Brussaard, C. P. D., Thyrhaug, R., Bratbak, G., and Vaulot, D.: Enumeration of marine viruses in culture and natural samples by flow cytometry, Appl. Environ. Microbiol., 65, 45-52, 1999.

Masotti, I., Moulin, C., Alvain, S., Bopp, L., Tagliabue, A., and Antoine, D.: Large-scale shifts in phytoplankton groups in the Equatorial Pacific during ENSO cycles, Biogeosciences, 8, 539-550, doi:10.5194/bg-8-539-2011, 2011.

Matsumoto, K. and Furuya, K.: Variations in phytoplankton dynamics and primary production associated with ENSO cycle in the western and central equatorial Pacific during 1994-2003, J. Geophys. Res., 116, C12042, doi:10.1029/2010JC006845, 2011. 
Matsumoto, K., Furuya, K., and Kawano, T.: Association of picophytoplankton with ENSO events in the equatorial Pacific between $145^{\circ} \mathrm{E}$ and $160^{\circ} \mathrm{W}$, Deep-Sea. Res. I, 51, 1851-1871, 2004

Mella-Flores, D., Six, C., Ratin, M., Partensky, F., Boutte, C., Le Corguillé, G., Marie, D., Blot, N., Gourvil, P., Kolowrat, C., and Garczarek, L.: Prochlorococcus and Synechococcus have evolved different adaptive mechanisms to cope with light and UV stress, Front. Microbiol., 3, 285, doi:10.3389/fmicb.2012.00285, 2012.

Michelou, V. K.: Uptake of dissolved organic matter and phosphate by phototrophic and heterotrophic bacteria, $\mathrm{PhD}$ dissertation, University of Delaware, 149 pp., 2009.

Michelou, V. K., Lomas, M. W., and Kirchman, D. L.: Phosphate and adenosine- $5^{\prime}$-triphosphate uptake by cyanobacteria and heterotrophic bacteria in the Sargasso Sea, Limnol. Oceanogr., 56, 323-332, 2011.

Moore, L. R., Goericke, R., and Chisholm, S. W.: Comparative physiology of Synechococcus and Prochlorococcus: influence of light and temperature on growth, pigments, fluorescence and absorptive properties, Mar. Ecol.-Prog. Ser., 116, 259-275, 1995.

Moutin, T., Thingstad, T. F., Van Wambeke, F., Marie, M., Slawyk, G., Raimbault, P., and Claustre, H.: Does competition for nanomolar phosphate supply explain the predominance of the cyanobacterium Synechococcus?, Limnol. Oceanogr., 47, 15621567, 2002.

Obayashi, Y., Tanoue, E., Suzuki, K., Handa, N., Nojiri, Y., and Wong, C. S.: Spatial and temporal variabilities of phytoplankton community structure in the Northern North Pacific as determined by phytoplankton pigment, Deep-Sea Res. I, 48, 439-469, 2001.

Oka, E.: Seasonal and interannual variation of North Pacific Subtropical Mode Water in 2003-2006, J. Phys. Oceanogr., 65, 151164, 2009.

Olson, R. J., Chisholm, S. W., Zettlern, E. R., Altabet, M. A., and Dusenberry, J. A.: Spatial and temporal distributions of prochlorophyte picoplankton, Biochem. Physiol. Pflan., 167, 191-194, 1990

Painchaud, J. and Therriault, J.-C.: Relationships between bacteria, phytoplankton and particulate organic carbon in the upper St. Lawrence estuary, Mar. Ecol.-Prog. Ser., 56, 301-311, 1989.

Partensky, F., Hess, W. R., and Vaulot, D.: Prochlorococcus, a marine photosynthetic Prokaryote of global significance, Microbiol. Mol. Biol. Rev., 63, 106-127, 1999.

Pearson, K.: On lines and planes of closest fit to systems of points in space, Philos. Mag., 2, 559-572, 1901.

Peterson, T. D., Crawford, D. W., and Harrison, P. J.: Evolution of the phytoplankton assemblage in a long-lived mesoscale eddy in the eastern Gulf of Alaska, Mar. Ecol.-Prog. Ser., 424, 53-73, 2011.

Qiu, B.: Seasonal eddy field modulation of the North Pacific Subtropical Countercurrent: TOPEX/Poseidon observations and theory, J. Phys. Oceanogr., 29, 2471-2486, 1999.

Qiu, B. and Chen, S.: Interannual variability of the North Pacific Subtropical Countercurrent and its associated mesoscale eddy field, J. Phys. Oceanogr., 40, 213-225, 2010.

Qiu, B. and Lukas, R.: Seasonal and interannual variability of the North Equatorial Current, the Mindanao Current, and the Kuroshio along the Pacific western boundary, J. Geophys. Res., 101, 12315-12330, 1996
Richardson, T. L. and Jackson, G. A.: Small phytoplankton and carbon export from the surface ocean, Science, 315, 838-840, 2007.

Rii, Y. M., Brown, S. L., Nencioli, F., Kuwahara, V., Dickey, T., Karl, D. M., and Bidigare, R. R.: The transient oasis: Nutrientphytoplankton dynamics and particle export in Hawaiian lee cyclones, Deep-Sea Res. II, 55, 1275-1290, 2008.

Rippka, R., Coursin, T., Hess, W., Lichte, C., Scalan, D. J., Palinska, K. A., Iteman, I., Partensky, F., Houmard, J., and Herdman, M.: Prochlorococcus marinus Chisholm et al. subsp. nov. pastoris, strain PCC9511, the first axenic chlorophyll $a 2 / b 2$-containing cyanobacterium (Oxyphotobacteria), Int. J. Syst. Evol. Microbiol., 50, 1833-1847, 2000.

Rousseaux, C. S. and Gregg, W. W.: Climate variability and phytoplankton composition in the Pacific Ocean, J. Geophys. Res. 117, C10006, doi:10.1029/2012JC008083, 2012.

Sato, M., Hashihama, F., Kitajima, S., Takeda, S., and Furuya, K.: Distribution of nano-sized cyanobacteria in the western and central Pacific Ocean, Aquat. Microb. Ecol., 56, 273-282, 2010.

Sekine, Y. and Miyamoto, S.: Influence of Kuroshio flow on the horizontal distribution of north Pacific intermediate water in the Shikoku basin, J. Oceanogr., 58, 611-616, 2002.

Selmer, J.-S., Ferrier-Pages, C., Cellario, C., and Rassoulzadegan, F.: New and regenerated production in relation to the microbial loop in the NW Mediterranean Sea, Mar. Ecol.-Prog. Ser., 100, 71-83, 1993.

Shimada, A., Hasegawa, T., Umeda, I., Kadoya, N., and Maruyama, T.: Spatial mesoscale patterns of West Pacific picophytoplankton as analysed by flow cytometry: their contribution to subsurface chlorophyll maxima, Mar. Biol., 115, 209-215, 1993.

Sieracki, M. E., Haugen, E. M., and Cucci, T. L.: Overestimation of heterotrophic bacteria in the Sargasso Sea: direct evidence by flow and imaging cytometry, Deep-Sea Res. I, 42, 1399-1409, 1995.

Steinberg, D. K., Carlson, C. A., Bates, N. R., Johnson, R. J., Michaels, A. F., and Knap, A. F.: Overview of the U.S. JGOFS Bermuda Atlantic Time-series Study (BATS): A decade-scale look at ocean biology and biogeochemistry, Deep-Sea Res. II, 48, 1405-1447, 2001.

Suzuki, K., Handa, N., Kiyosawa, H., and Ishizaka, J.: Distribution of the prochlorophyte Prochlorococcus in the central Pacific Ocean as measured by HPLC, Limnol. Oceanogr., 40, 983-989, 1995.

Suzuki, K., Handa, N., Kiyosawa, H., and Ishizaka, J.: Temporal and spatial distribution of phytoplankton pigments in the central Pacific Ocean along $175^{\circ}$ E during the Boreal Summers of 1992 and 1993, J. Oceanogr., 53, 383-396, 1997.

Thomson, R. E. and Fine, I. V.: Estimating mixed layer depth from oceanic profile data, J. Atmos. Ocean. Tech., 20, 319-329, 2003.

Thyssen, M., Lefèvre, D., Caniaux, G., Ras, J., Fernandez, C. F., and Denis, M.: Spatial distribution of heterotrophic bacteria in the northeast Atlantic (POMME study area) during spring 2001, J. Geophys. Res., 110, C07S16, doi:10.1029/2004JC002670, 2005.

Tomczak, M. and Godfrey, J. S.: Regional oceanography: an introduction, Pergamon Press, Oxford, 1994.

Vaillancourt, R. D., Marra, J., Seki, M. P., Parsons, M. L., and Bidigare, R. R.: Impact of a cyclonic eddy on phytoplankton community structure and photosynthetic competency in the subtropical North Pacific Ocean, Deep-Sea Res. I, 50, 829-847, 2003. 
White, W. B., Hasunuma, K., and Solomon, H.: Large-scale seasonal and secular variability of the Subtropical Front in the western North Pacific from 1954 to 1974, J. Geophys. Res., 83, 45314544, 1978.

Xie, L., Tian, J., Hu, D., and Wang, F.: A quasi-synoptic interpretation of water mass distribution and circulation in the western North Pacific: I. Water mass distribution, Chin. J. Oceanol. Limnol., 27, 630-639, 2009.
Zehr, J. P., Waterbury, J. B., Turner, P. J., Montoya, J. P., Omoregie, E., Steward, G. F., Hansen, A., and Karl, D. M.: Unicellular cyanobacteria fix $\mathrm{N}_{2}$ in the subtropical North Pacific Ocean, Nature, 412, 635-638, 2001.

Zhang, Y., Jiao, N., and Hong, N.: Comparative study of picoplankton biomass and community structure in different provinces from subarctic to subtropical oceans, Deep-Sea Res. II, 55, 16051614, 2008. 